\title{
Nanomaterials for Treating Bacterial Biofilms on Implantable Medical Devices
}

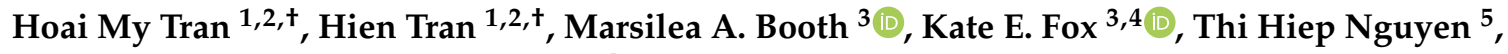 \\ Nhiem Tran ${ }^{6}$ and Phong A. Tran ${ }^{1,2, *(D)}$ \\ 1 Centre for Biomedical Technologies, Queensland University of Technology (QUT), 2 George Street, \\ Brisbane, QLD 4000, Australia; h39.tran@hdr.qut.edu.au (H.M.T.); anhhien.tran@hdr.qut.edu.au (H.T.) \\ 2 Interface Science and Materials Engineering Group, School of Mechanical, Medical and Process Engineering, \\ Queensland University of Technology, Brisbane, QLD 4000, Australia \\ 3 School of Engineering, RMIT University, Melbourne, VIC 3001, Australia; \\ marsilea.harrison@rmit.edu.au (M.A.B.); kate.fox@rmit.edu.au (K.E.F.) \\ 4 Center for Additive Manufacturing, RMIT University, PO Box 2476, Melbourne, VIC 3001, Australia \\ 5 School of Biomedical Engineering, International University, Vietnam National University, \\ Ho Chi Minh City 71300, Vietnam; nthiep@hcmiu.edu.vn \\ 6 School of Science, RMIT University, Melbourne, VIC 3001, Australia; nhiem.tran@rmit.edu.au \\ * Correspondence: phong.tran@qut.edu.au; Tel.: +61-07-3318-6452 \\ + These authors contributed equally to this work.
}

Received: 20 October 2020; Accepted: 11 November 2020; Published: 13 November 2020

\begin{abstract}
Bacterial biofilms are involved in most device-associated infections and remain a challenge for modern medicine. One major approach to addressing this problem is to prevent the formation of biofilms using novel antimicrobial materials, device surface modification or local drug delivery; however, successful preventive measures are still extremely limited. The other approach is concerned with treating biofilms that have already formed on the devices; this approach is the focus of our manuscript. Treating biofilms associated with medical devices has unique challenges due to the biofilm's extracellular polymer substance (EPS) and the biofilm bacteria's resistance to most conventional antimicrobial agents. The treatment is further complicated by the fact that the treatment must be suitable for applying on devices surrounded by host tissue in many cases. Nanomaterials have been extensively investigated for preventing biofilm formation on medical devices, yet their applications in treating bacterial biofilm remains to be further investigated due to the fact that treating the biofilm bacteria and destroying the EPS are much more challenging than preventing adhesion of planktonic bacteria or inhibiting their surface colonization. In this highly focused review, we examined only studies that demonstrated successful EPS destruction and biofilm bacteria killing and provided in-depth description of the nanomaterials and the biofilm eradication efficacy, followed by discussion of key issues in this topic and suggestion for future development.
\end{abstract}

Keywords: bacteria; biofilm; nanomaterials; treatment; infection; in situ

\section{Introduction}

Despite hygienic techniques and prophylactic antibiotics, infection rates of primary implants remain clinically significant. In the US alone, infections related to medical devices account for $45 \%$ of total nosocomial (hospital-based) infections [1], with approximately one million cases per year [2]. Device-associated infection is predominantly linked with bacterial biofilm formation. Biofilms can form on most medical devices from a wide range of bacterial species [3]. The process initiates with bacterial adherence to the device surfaces or the compromised surrounding tissue. Bacteria then proliferate, colonize and form the biofilm consisting of bacterial cells enclosed in the secreted 
extracellular polymeric substances (EPS) (Figure 1) [4,5]. The EPS comprises polysaccharides, nucleic acids, proteins and lipids [5,6] with an acidic microenvironment caused by hypoxia and anaerobic glycolysis [6-8]. The biofilm provides bacterial cells with protection against shear stress, host immune defence and antibiotic actions [9-11]. Moreover, bacterial cells released from biofilms and can cause local recurrence or infection at other sites by haematogenous dissemination $[3,10]$.

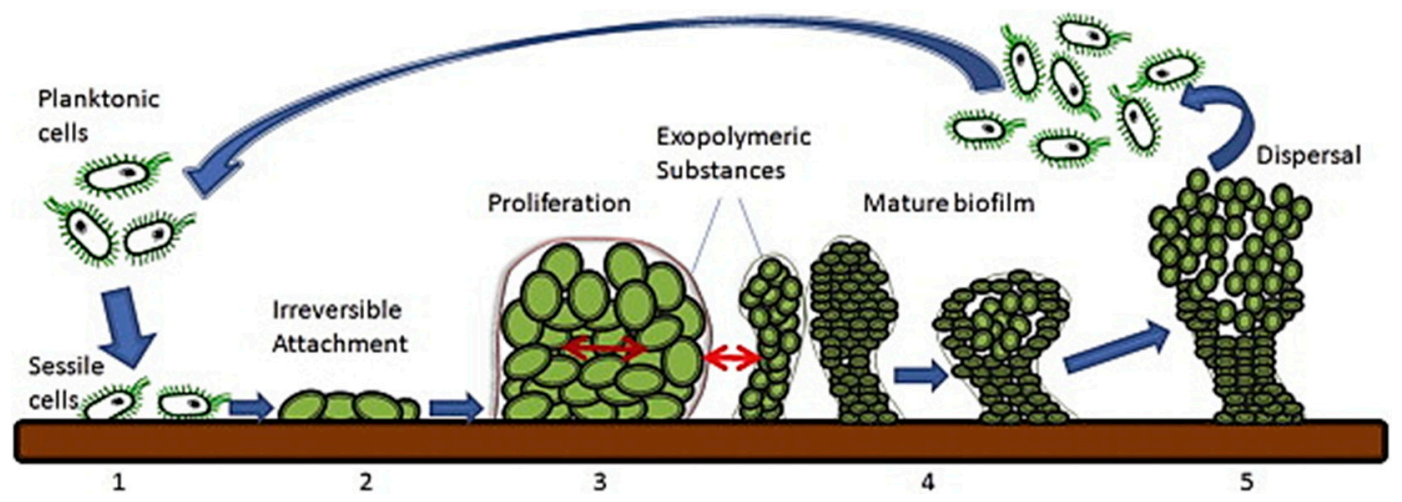

Figure 1. Biofilm formation and dispersion. (1) Bacterial cell attachment onto the surface. (2) Bacterial cells becoming irreversibly attached. (3) Bacterial proliferation and EPS secretion. (4) Biofilm formation and maturation. (5) Biofilm dispersal and mobility of planktonic cells (reproduced from [12] with permission from Elsevier, 2015).

One major strategy in the infection control of implantable medical devices is to prevent biofilm formation. The gold standard for biofilm prevention involves aseptic techniques and antibiotic prophylaxis $[13,14]$. Systemic administration and local antibiotic reservoirs have been frequently employed as prophylactic means in clinical settings [15-18]. More advanced preventive measures, still in research and development, include new biomaterials with intrinsic antimicrobial properties or surface modification with antimicrobial moieties. The main rationales behind these designs are based on the concept of 'race for the surface' put forward by Gristina in 1987 [19], which postulated that bacteria and mammalian cells compete for available binding sites on the implant surface and implant success depends largely on who wins this competition. Prevention of bacterial colonization and biofilm formation thus should allow tissue cells to form a natural protective layer on the implant. Yet, despite a large number of in vitro and in vivo studies demonstrating promising biofilm-preventing results [20-22], only very few have been successfully translated to clinical applications. For example, besides local antibiotic depots that were not specifically designed to act as antimicrobial implant surface treatments, only four technologies have become commercially available technologies or have shown clinical efficacy in orthopaedics and trauma for clinical use, including silver coating, iodine coating, gentamicin-poly(D,L-lactide) (PLLA) coating, and PLLA-linked hyaluronan hydrogel coating containing antibiotics [23]. Even so, the efficacy of these four technologies in large clinical trials remain to be proven.

Clinically, treating device-associated biofilms is most relevant in device/implant retention surgery. In contrast to the common one- or two-stage device exchange surgeries [24] where infected devices are removed and replaced by a new implant, the implant retention surgery (also known as 'debridement, antibiotics and implant retention-DAIR') is less invasive and preferable in scenarios such as early or acute infection. The success rate of DAIR heavily depends on the ability to effectively eradicate the biofilms [25], yet it is well recognized that the biofilm's EPS provides a protective matrix which reduces the penetration of antimicrobial agents and the embedded, dormant biofilm bacteria are highly resistant to conventional antimicrobial agents such as antibiotics [26].

There are already many excellent reviews on medical device-associated bacterial biofilms, their implication in infections, or strategies to prevent their formation, such as those by Rodney [27], Hall-Stoodley [28], or Ferraris and colleagues [29,30]. Several recent publications have also reviewed 
the methods of eradicating these biofilms, such as the work by Verderosa et al. [31]. In the current paper, we focused on reviewing nanomaterials, a subset of biomaterials, in eradicating bacterial biofilm. In particular, we only examined studies that demonstrated success in destroying the EPS and killing the embedded bacteria rather than preventing biofilm formation. Here, we focused on the key, most promising nanomaterials and provided details of the most significant results to offer a highly focused and in-depth review of the topic and provide readers with clear comparison of the synthesis and effectiveness of these materials to guide future development.

\section{Nanomaterials for Treating Bacterial Biofilms on Medical Devices}

In this section, we categorized the nanomaterials in biofilm treatment into three groups, including (i) nanomaterials with intrinsic biofilm-eradicating properties, (ii) nanomaterials as delivery vehicles for biofilm-eradicating agents, and (iii) responsive nanomaterials (Figure 2).

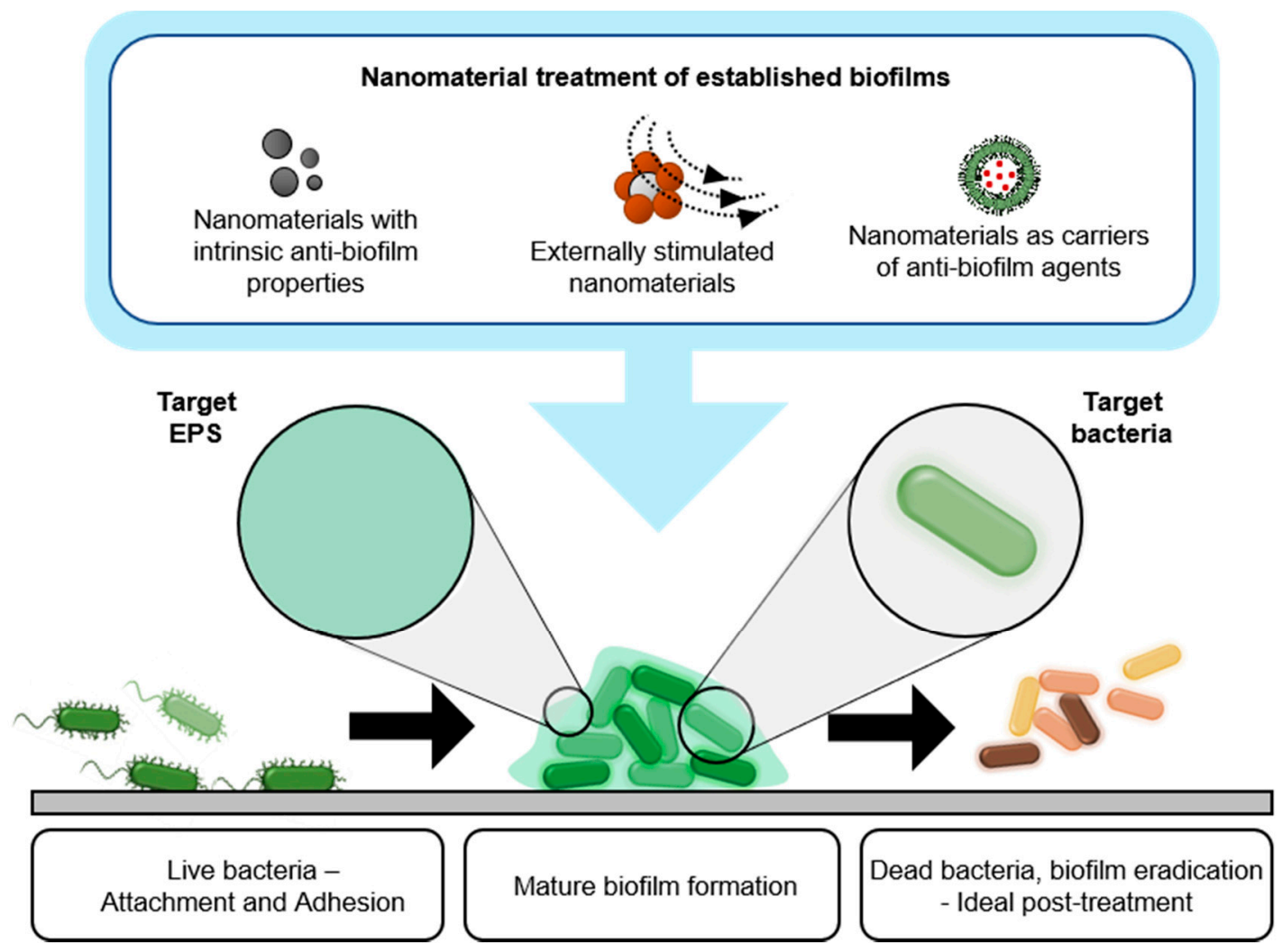

Figure 2. Schematic indicating the growth of mature bacterial biofilm and three major types of nanomaterials for biofilm treatment: (i) intrinsically biofilm-eradicating nanomaterials, (ii) nanocarriers of biofilm-eradicating agents, and (iii) responsive biofilm-eradicating nanomaterials.

\subsection{Nanomaterials with Intrinsic Biofilm-Eradicating Properties}

Despite the fact that there is a large number of nanomaterials with intrinsic bactericidal properties, which have been reviewed elsewhere, only some nanomaterials have been shown to have the intrinsic abilities to destroy the EPS or killing bacterial biofilm [32,33]. Most of the intrinsic biofilm-eradicating nanomaterials are derived from bactericidal nanomaterials and thus they were often also demonstrated to have effects on biofilm formation as reviewed below.

A key type of nanoparticle with intrinsic anti-biofilm activities is metallic nanoparticles. Certain metallic nanoparticles can release soluble ions that target bacteria or the EPS; some can interact with the biofilm's EPS as a result of surface functional groups or charge interaction [6,34-37]. Silver is among the most studied metallic nanomaterials with high bactericidal properties on a broad 
spectrum of microorganism species and has been shown to be able to eradicate biofilms. In one study, Salunke et al. [38] synthesized AgNPs from plant extract and investigated their antimicrobial properties on Acinetobacter baumannii, E. coli and S. aureus, using the disk diffusion test. They showed that AgNPs inhibited bacterial growth with low minimum inhibitory concentration $(2 \mu \mathrm{g} / \mathrm{disk}$ against $E$. coli and $8 \mu \mathrm{g} /$ disk against $A$. baumannii and S. aureus), compared to the chemically synthesized AgNPs used as a control. In biofilm disruption assays, the biofilms were grown for $24 \mathrm{~h}$. The results show that AgNPs could disrupt $88 \%, 67 \%$, and $78 \%$ of A. baumannii, E. coli and S. aureus biofilms, respectively; and $64 \%$ of mixed biofilm after $24 \mathrm{~h}$ treatment at $37^{\circ} \mathrm{C}$ [38]. In another study, Gaidhani et al. used Acinetobacter calcoaceticus to synthesize silver nanoparticles (AgNPs) with sizes ranging from 4-40 nm and showed that the nanoparticles were able to disrupt biofilms of 20 different pathogenic bacteria [39].

Some researchers showed anti-biofilm activity of gold nanoparticles. For example, Habimana et al. [40] developed gold particles (GNP) functionalized with enzyme proteinase K (denoted as GNP + PK) and tested them against Pseudomonas fluorescens biofilms which were formed for $72 \mathrm{~h}$. The biofilm volume, measured from 3D confocal laser scanning microscopy, was found to decrease by $40 \%, 77 \%$, and $74 \%$ after $24 \mathrm{~h}$ treatment with proteinase K (PK), GNP, and GNP + PK, respectively. The combined GNP + PK was able to reduce the biofilm thickness by 78\%, while PK and GNP induced a reduction of 52\% and $72 \%$, respectively. Overall, the GNP + PK particles displayed greater antimicrobial/antibiofilm effects than either PK or GNP alone by causing structural damage to the biofilm, killing sessile cells within the biofilm and mechanically dispersing the cells in suspension [40].

Several research groups have also investigated polymeric nanomaterials with inherent anti-biofilm properties. These materials often work through mechanisms related to electrostatic interactions with bacteria and biofilm's EPS, which usually have a negatively charge on the outer layer [41-43] Chitosan is a commonly used charged polymer that has high antibacterial activity. Mohamed et al. developed chitosan nanoparticles and tested on multi-species biofilm in the root canal, which inhibited $97 \%$ and $94 \%$ of the formation of biofilm in single and mixed-species biofilm, respectively. Furthermore, the chitosan nanoparticles also gradually disrupted the one-week pre-formed mixed-species biofilm for 8 days (5-log reduction) [44]. In another study, chitosan nanoparticles were tested against a 7 day old E. faecalis biofilm. After incubating with chitosan nanoparticles at $37^{\circ} \mathrm{C}$ for $72 \mathrm{~h}$, the authors found that the chitosan concentration of $5 \mathrm{mg} / \mathrm{mL}$ induced a maximum reduction in biofilm bacteria viability of 4 logs; and at the concentration of $20 \mathrm{mg} / \mathrm{mL}$, most bacterial cells were completely killed [45]. In another study, Zhu et al. [46] showed that cationic PLGA nano-polymer could inhibit the growth of Streptococcus mutants over a $24 \mathrm{~h}$ period, with most bacteria being killed after 90 min. Furthermore, the cationic nano-polymer totally disintegrated 1 day old biofilms and induced $73 \%$ bacterial death at the concentration of $100 \mu \mathrm{g} / \mathrm{ML}$ [46]. In yet another study, Harper et al. [47] combined the effects of electrolyte charge screening and anionic (+) alpha-tocopherol phosphate ( $\alpha$-TP) liposome nanoparticles to enhance the diffusion through biofilm of the latter (Figure 3). The bacterial biofilm was grown for $18 \mathrm{~h}$ before being treated with the nanoparticles for $2 \mathrm{~min}$. The self-assembled $700 \mathrm{~nm}$ liposomes had a zeta potential of $-20 \mathrm{mV}$ and could not penetrate the oral multispecies oral biofilms (from a donor) in a phosphate (-ve) buffer. In a tris(hydroxymethyl)aminomethane (+ve) buffer, the liposomes were found to penetrate $12.4 \pm 3.6 \mu \mathrm{m}$ into the biofilms and kill the embedded microbes [47]. 


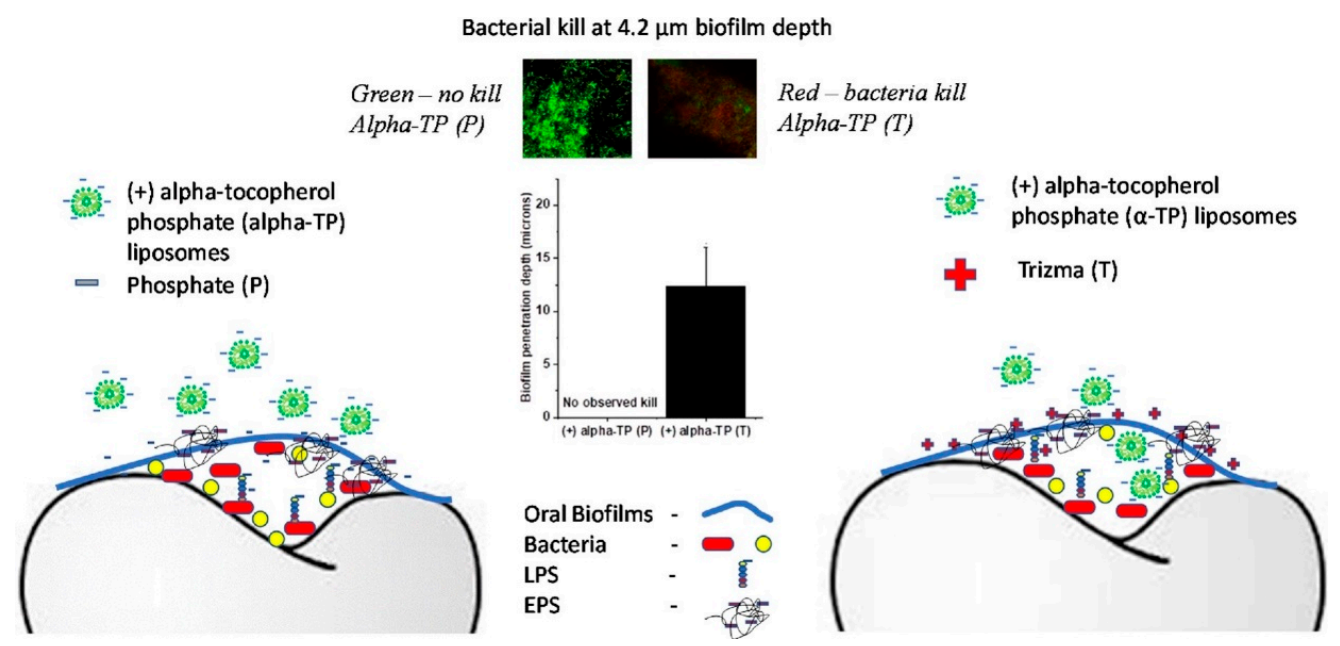

Figure 3. Schematic of biofilm elimination by combination of charge screening and alpha-tocopherol phosphate $(\alpha-\mathrm{TP})$ charged liposome nanoparticles. The penetration of negatively charged $\alpha$-TP liposomes were enhanced in the Tris buffer (positively charged) causing bacteria death as compared to poor penetration and ineffective in phosphate buffer saline (PBS) (reproduced from [47] with permission from Elsevier, 2015).

\subsection{Nanomaterials as Carriers of Biofilm-Eradicating Agents}

The interactions between the biofilm, bacteria and antimicrobial agents are crucial in treating bacterial biofilms [6]. For therapies targeting biofilm bacteria, penetration into the biofilm is crucial. Antimicrobial compounds may not be able to reach the bacteria in a mature biofilm for several reasons, such as reduced diffusion across the EPS, drug degradation, or the poor interactions with biofilm components [48-50]. Nanoparticles can act as drug delivery vehicles that could address these problems. These nanocarriers with their intrinsic high surface-area-to-volume ratio and rich surface chemistry can be designed to have a controllable therapeutic dose, improve the stability of their 'cargo', or temporal and spatial cargo release. Nanocarriers can be made from various organic (e.g., lipid and polymer) and inorganic materials $[49,51]$ and some even have intrinsic antimicrobial or antibiofilm properties $[52,53]$.

A straightforward design involves using antibiotics in nanocarriers. In one example, Elbi et al. [54] developed chitosan nanoparticles containing ciprofloxacin and coated with Fucoidan to enhance antimicrobial activity and the endocytosis of the material into macrophages to kill intracellular bacteria. The authors showed that the nanocarriers effectively dispersed the 2 day old S. Paratyphi A biofilm, significantly more effective than ciprofloxacin alone (1.6 times better) and were not toxic to RAW 264.7 macrophages after $48 \mathrm{~h}$ of treatment. Furthermore, the nanocarriers also entered the macrophages and killed the intracellular S. Paratyphi $A$ in a coculture model [54]. Mu et al. [55] utilized a similar concept for $P$. aeruginosa and S. aureus biofilm treatment. In this case, gentamicin was loaded in phosphatidylcholine-decorated AuNPs (GPA NPs) and the loaded nanoparticles were shown to eliminate $78 \%, 65 \%, 71 \%$ and $69 \%$ of the biofilms of P. aeruginosa, S. aureus, E. coli, and L. monocytogenes, respectively. Furthermore, GPA NPs were nontoxic to murine macrophage cells and also reduced the viability of intracellular bacteria from $5 \times 10^{7}$ to $1 \times 10^{5} \mathrm{CFU}$ and $3.5 \times 10^{6}$ to $0.5 \times 10^{6} \mathrm{CFU}$ for P. aeruginosa and L. monocytogenes in the infected macrophages, respectively [55].

Besides nanocarriers containing antibiotics, other nanocarrier systems have also been developed to deliver non-drug agents, such as enzymes or essential oils. Tan et al. [53] utilized positively charged chitosan nanoparticles as a nanocarrier for deoxyribonuclease I (DNase I, used to target biofilm's extracellular DNA) and oxacillin to target $S$. aureus biofilms. The loaded polymer nanoparticles were shown to eradicate $70 \%$ and $100 \%$ of a S. aureus mature biofilm at oxacillin concentration of 0.0625 and $2 \mu \mathrm{g} / \mathrm{mL}$, respectively after $24 \mathrm{~h}$ of treatment [53]. In another example, poly(lactic-co-glycolic acid) (PLGA) nanoparticles coated with poly(lysin) (PL) were used as the nanocarriers for ciprofloxacin 
(Cip) and DNase I. Tested nanoparticle formulations comprised PLGA-PL-Cip, PLGA-PL-Cip + PLGA-PL-DNase I, and PLGA-PL-Cip-DNase I. The nano-systems were investigated against a biofilm of the Gram-negative bacteria P. aeruginosa. In this study, the biofilm was cultivated at $37^{\circ} \mathrm{C}$ in flow cell chamber for 4 days and treated with different nano-formulations for $24 \mathrm{~h}$ and the biomass and thickness of the biofilm were evaluated. The biomass and thickness reduced by $24 \%$ and $50 \%$, respectively, in the PLGA-PL-Cip group, and by $29 \%$ and $52 \%$ in the combined PLGA-PL-Cip + PLGA-PL-DNase I group. In particular, the last group (PLGA-PL-Cip-DNase I) showed the best efficacy with a reduction of $43 \%$ in biomass and $63 \%$ in thickness. Moreover, this formulation also eradicated over $95 \%$ of the 2 day old biofilm at a concentration of antibiotic as low as $0.0078 \mu \mathrm{g} / \mathrm{mL}$ [56].

Duncan et al. [57] evaluated the use of silica nanoparticles functionalized with either peppermint oil (P-Cap) alone or in combination with cinnamaldehyde (CP-Cap) to disrupt and destroy E. coli DH5, P. aeruginosa, S. aureus, and Enterobacter cloacae complex biofilms (Figure 4). The biofilm was cultivated for 1 day before being treated with nanoparticles. After $3 \mathrm{~h}$ of CP-Cap treatment, the results show that these nanoparticles had the ability to reduce of the biofilm bacteria viability by $100 \%$ in all biofilms of P. aeruginosa, E. coli, S. aureus, and E. cloacae complex at $2 \%$ of emulsion solution. Meanwhile, bacterial colony forming units of $E$. coli biofilm also decreased by 4 logs after $3 \mathrm{~h}$ treatment of CP-Cap in a co-culture experiment. This nanoparticle formulation displayed the highest efficacy of biofilm eradication and bacterial killing among the formulations tested. The P-Cap and control groups, in contrast, were not effective [57].

a)
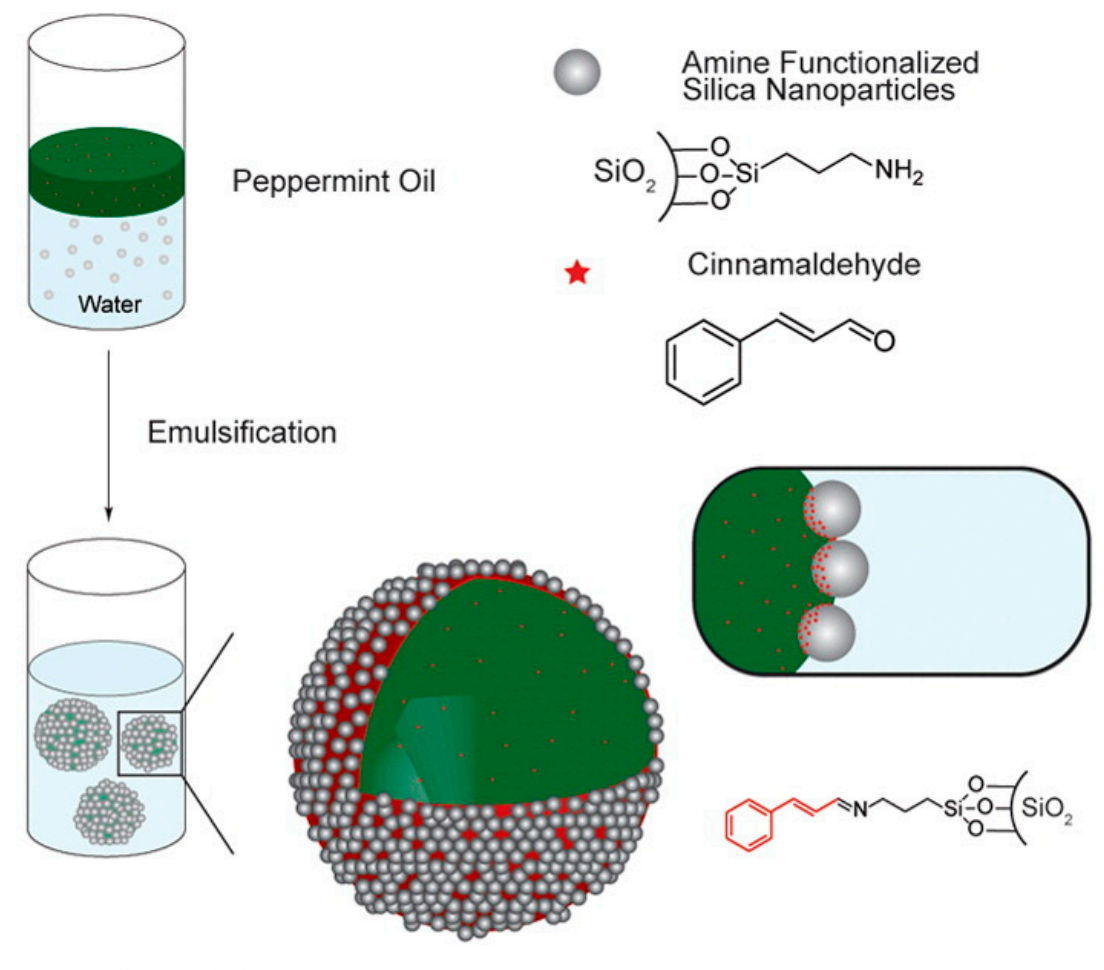

Amine Functionalized
Silica Nanoparticles

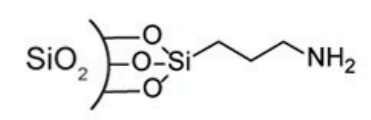

$\star \quad$ Cinnamaldehyde

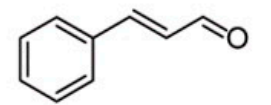

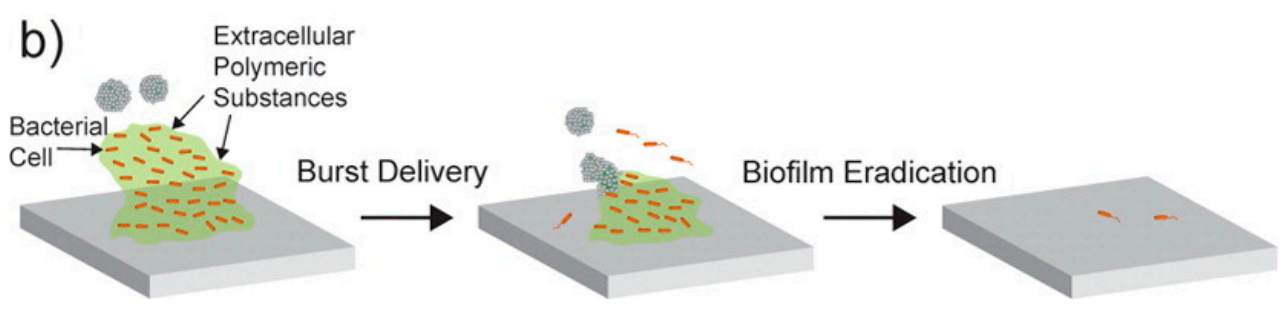

Figure 4. (a) Schematic describing the preparation of nanocarriers loaded with antimicrobial agents by an emulsification method, and (b) illustration of functionalized silica nanocarriers for bacterial biofilm treatment (reproduced from [57] with permission from American Chemical Society, 2015). 
Landis et al. [58] investigated the potential of using oil-in-water emulsification to fabricate nanocomposites containing carvacrol oil (X-NCs) to treat P. aeruginosa, S. aureus, E. coli, and E. cloacae biofilms. After $3 \mathrm{~h}$ of treatment, the bacterial viability in 1 day old biofilms was remarkably reduced by 95-90\% for all bacterial types. Landis also investigated the effectiveness of X-NCs in a coculture by seeding the bacterial cells with a monolayer of fibroblasts overnight to form the biofilm. After $3 \mathrm{~h}$ of treatment with $10 \mathrm{wt} \%$ X-NCs, the number of biofilm bacteria was reduced $4 \mathrm{log}$, whilst the viability of the fibroblasts was maintained [58].

Another group of nanocarriers are based on the delivery of nitric oxide (NO) as a reactive free radical. Several studies have used this agent in the form of nanoparticles for biofilm eradication. As an example, Slomberg et al. [59] conjugated NO to silica nanoparticles and tested them against $S$. aureus and P. aeruginosa biofilms. The biofilms were cultivated for $48 \mathrm{~h}$ in a bioreactor before being treated with the nanoparticles for $24 \mathrm{~h}$. The results show that the size and shape of the nanoparticles influenced the efficacy of biofilm eradication. The smaller size of silica particles displayed higher ability in treating $P$. aeruginosa biofilm, with the minimum bactericidal concentration (MBC) of $6 \mathrm{mg} / \mathrm{mL}$ for the $14 \mathrm{~nm}$ particles compared with $10 \mathrm{mg} / \mathrm{mL}$ for the $150 \mathrm{~nm}$ particles. Moreover, the spherical shape of silica particles showed MBC of 12 and $8 \mathrm{mg} / \mathrm{mL}$ for S. aureus and P. aeruginosa, respectively, compared with 4 and $1 \mathrm{mg} / \mathrm{mL}$ for rod shape particles [59]. Mihu et al. synthesized NO-containing nanoparticles from a combination of polyethylene glycol, glucose, chitosan and sodium nitrite. It was found that the nano-platform was able to interfere with biofilm formation on central venous catheters both in vitro and in vivo. In an in vitro biofilm formation study, a $5 \mathrm{~mm}$-long catheter was placed into the MRSA culture and incubated for $24 \mathrm{~h}$ at $37^{\circ} \mathrm{C}$ under shaking condition to form the biofilm. The colonized catheter was then treated with $5 \mathrm{mg} / \mathrm{mL}$ of NO-nanoparticles for $24 \mathrm{~h}$. The treatment resulted in a $75 \%$ decrease in biofilm bacteria viability compared to that of the untreated control. The authors also inserted catheters into veins of rats and inoculated the lumens with MRSA to form biofilm in vivo. After $24 \mathrm{~h}$, a single dose of $5 \mathrm{mg} / \mathrm{mL}$ NO-nanoparticles or PBS (as a control) was injected into the catheter lumens to treat the biofilms. After $48 \mathrm{~h}$, the authors found that NO-nanoparticle treatment resulted in roughly a $1 \log$ reduction of $\mathrm{CFU} / \mathrm{cm}^{2}$ compared to the control and that samples treated with NO-nanoparticles had only a small number of bacterial clusters without biofilm slime, compared to presence of abundant biofilm on the untreated control [60]. This study thus showed that these promising nanoparticles need to be further investigated and optimization.

\subsection{Treating Biofilms with Responsive Nanomaterials}

Magnetic field, light, or the $\mathrm{pH}$ of the micro-environment have been exploited to activate a nanomaterial or transform it into a more active species for destroying bacterial biofilms. These nanomaterials are often metallic nanoparticles or nanocarriers that exert physical disruption to bacterial biofilms [1,61]. Their advantages include rich surface chemistry and the nanoscale dimensions, which promote infiltration into the biofilms as well as targeting bacteria when activated or transformed. Additionally, some non-specific biofilm disruption mechanisms such as heat and physical force allow for a wide range of bacterial biofilms to be targeted [51,62].

\subsubsection{Magnetically Responsive Nanomaterials}

The main mechanism of this strategy is that a magnetic field is used to exert forces on magnetic nanoparticles and thus facilitates the penetration of nanoparticles into the biofilm [63]. Taylor et al. fabricated iron oxide nanoparticles (IONs) conjugated with metal ions and showed that after $24 \mathrm{~h}$ treatment under the magnetic field, the magnetic IONs conjugated with zinc, silver, and iron ions at concentration $370 \mu \mathrm{g} / \mathrm{mL}$ could disrupt up to $85 \%, 40 \%$, and $50 \%$ of the $24 \mathrm{~h}$ old S. aureus biofilm, respectively [64]. This concept was also applied by Leuba et al. [65] for the disruption of S. aureus biofilms where amine, carboxylate and isocyanate-functionalized superparamagnetic-ION were used to increase their diffusion into the biofilm and consequently enhance biofilm disruption. Amine, carboxylate, and isocyanate functionalized disrupted $28.1 \%, 33.5 \%$, and $31.1 \%$ of $24 \mathrm{~h}$ old $S$. aureus biofilm after 
$24 \mathrm{~h}$ of treatment, respectively, higher than superparamagnetic IONs alone. This phenomenon was explained by the catabolism of carbon and nicotinamide adenine dinucleotide (NADH) generation involved in biofilm eradication [65]. A different study by Zhang et al. developed a nanohybrid complex containing silver and iron oxide. In the absence of a magnetic field, the nanohybrid complexes disrupted only $50 \%$ and $40 \%$ of E. coli and P. aeruginosa biofilms, respectively. However, the treatment efficacy was significantly improved ( $88 \%$ in E. coli and $90 \%$ in P. aeruginosa) in the presence of a magnetic field [66]. The study also showed that iron oxide promoted the penetration of silver nanoparticles, which then killed the microorganisms. This strategy is still at the proof-of-principle stage where the experiments are usually set up so that the nanoparticles are pulled toward biofilms grown on a substrate by using magnets placed underneath the substrate. In future clinical application, this method needs to be further optimized considering important factors such as the types of implants and their geometry/physiological locations.

\subsubsection{Local $\mathrm{pH}$ or Exogenous $\mathrm{H}_{2} \mathrm{O}_{2}$ - Responsive Nanomaterials}

In an acidic environment, certain nanomaterials can catalyze the production of oxidative species. As a result, stimuli such as local $\mathrm{pH}$ and/or $\mathrm{H}_{2} \mathrm{O}_{2}$ can be exploited to assist in the treatment of biofilms. Gao et al. [67] developed iron oxide nanoparticles (ION) with peroxide-like activity for attacking bacteria (E. coli) and biofilm (P. aeruginosa). The nanoparticles catalyzed $\mathrm{H}_{2} \mathrm{O}_{2}$ into free radicals through the Fenton reaction $[68,69]$. This study showed that $82 \%$ of $P$. aeruginosa biofilm was eliminated and $98 \%$ of $E$. coli were killed within 5 min of exposure to peroxide-like ION [67]. A later study by Gao et al. also reported that peroxide-like ION could disrupt $S$. mutants oral biofilm in vitro and in vivo in rodent dental caries [70]. The particles were shown to kill $99.9 \%$ of $S$. mutants within 5 min and degraded approximately $57 \%$ of in vitro $S$. mutants biofilm. In vivo, the particles alone could reduce the severity of moderate and extensive stage caries in rodents after topical treatment. Meanwhile, the particles in combination with $\mathrm{H}_{2} \mathrm{O}_{2}$ were able to completely remove the extensive caries preventing the distinct cavitation. The particles were also non-toxic to other cell types and organs when being applied topically on rodent caries. The particles also released iron ions, which helped in decreasing the acid dissolution of bone mineral, hydroxyapatite. A schematic describing the effects of the nanoparticle platform on bacterial biofilms is shown in Figure 5, where the ION infiltrated the bacterial biofilm, and upon addition of $\mathrm{H}_{2} \mathrm{O}_{2}$ caused bacterial cell death and biofilm disruption. This peroxide-like ION was also found to be more effective than chlorhexidine, a commonly used antimicrobial agent [70].
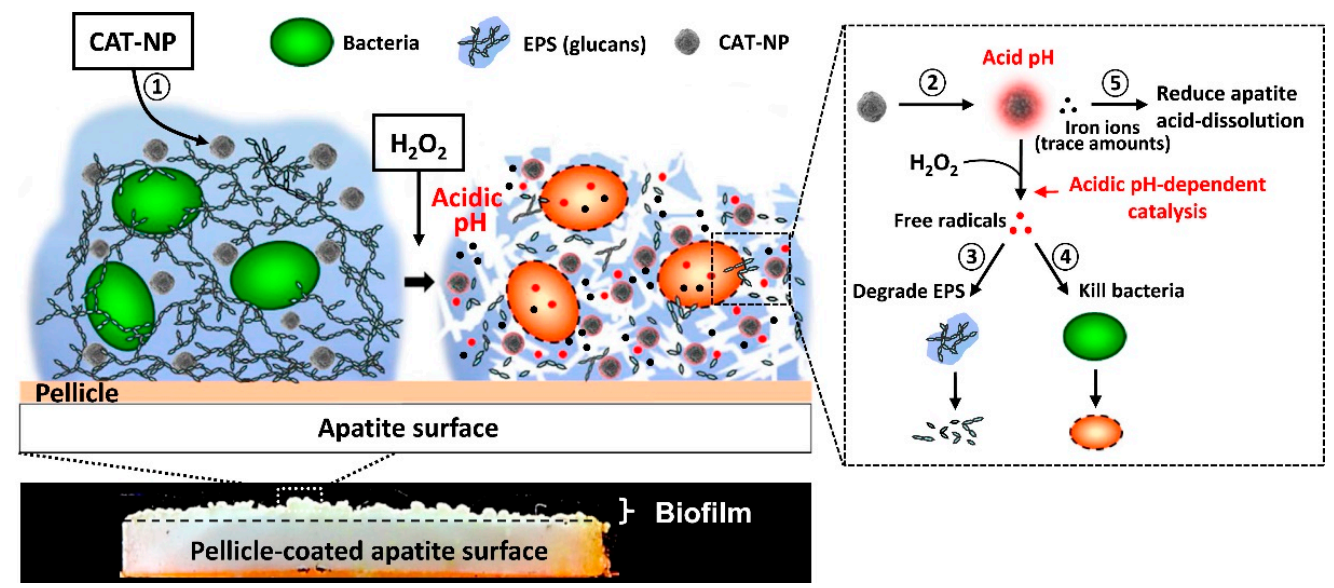

Figure 5. Schematic of biofilm disruption using hydrogen peroxide and iron oxide nanoparticles (ION). (1) The CAT-NP distributed in 3D biofilm structure after a brief topical exposure. (2) The CAT-NP catalyzed $\mathrm{H}_{2} \mathrm{O}_{2}$ via the Fenton reaction under acidic condition to produce free radicals. The generated free radicals (3) degraded EPS and (4) killed bacteria inside the biofilm. (5) CAT-NP were also able to release iron ions that can reduce acid dissolution of hydroxyapatite (reproduced from [70] with permission from Elsevier, 2016). 
A study by Horev et al. [8] provided an example of $\mathrm{pH}$-activated nanomaterials. Here polymeric-based nanoparticles comprised of 2-(dimethylamino)ethyl methacrylate (DMAEMA), butyl methacrylate (BMA) and 2-propylacrylic acid (PAA) (p(DMAEMA)-b-p(DMAEMA-co-BMA-co-PAA)) containing farnesol for $S$. mutants biofilms treatment were developed. The nanoparticles showed high binding affinity to the biofilm and were also sensitive to an acidic environment, causing the release of free farnesol, a hydrophobic bactericidal agent. The results show that the nanoparticles effectively disrupted the biofilm and reduced $80 \%$ of bacteria and increased biofilm removal by two-fold after five applications over a $44 \mathrm{~h}$ period [8].

\subsubsection{Light/Heat-Responsive Nanomaterials}

Another key strategy is photodynamic treatment or photothermal ablation, which is based on light-induced transformation or degradation of nanomaterials into biofilm-destroying species, or the generation of heat. Tierlinck et al. [71] investigated vapor nanobubbles (VNB) induced by the laser. The gold nanoparticles (70 $\mathrm{nm}$ in size) were able to deeply penetrate into the biofilm because of their small size. The gold nanoparticles (AuNPs) then received a high-energy laser pulse and induced rapid water evaporation and produced nanobubbles. The produced nanobubbles then created gaps within the biofilm, thus facilitating antibiotic penetration and transport. The results show synergy of VNB and tobramycin which resulted in approximately 80, 20, and 25 times CFU reduction in $24 \mathrm{~h}$ old B. multivorans, P. aeruginosa, and S. aureus biofilms after $3 \mathrm{~min}$ laser application and $24 \mathrm{~h}$ tobramycin treatment, respectively [71]. In a later study, the authors used these laser-induced VNB to functionalize the nanocarriers containing antibiotics for P. aeruginosa biofilm treatment (Figure 6). The AuNPs functionalized liposomes containing tobramycin reduced the CFU and biofilm biomass by approximately four times and 1.5 times as compared to untreated and liposomes containing tobramycin only, respectively [72].

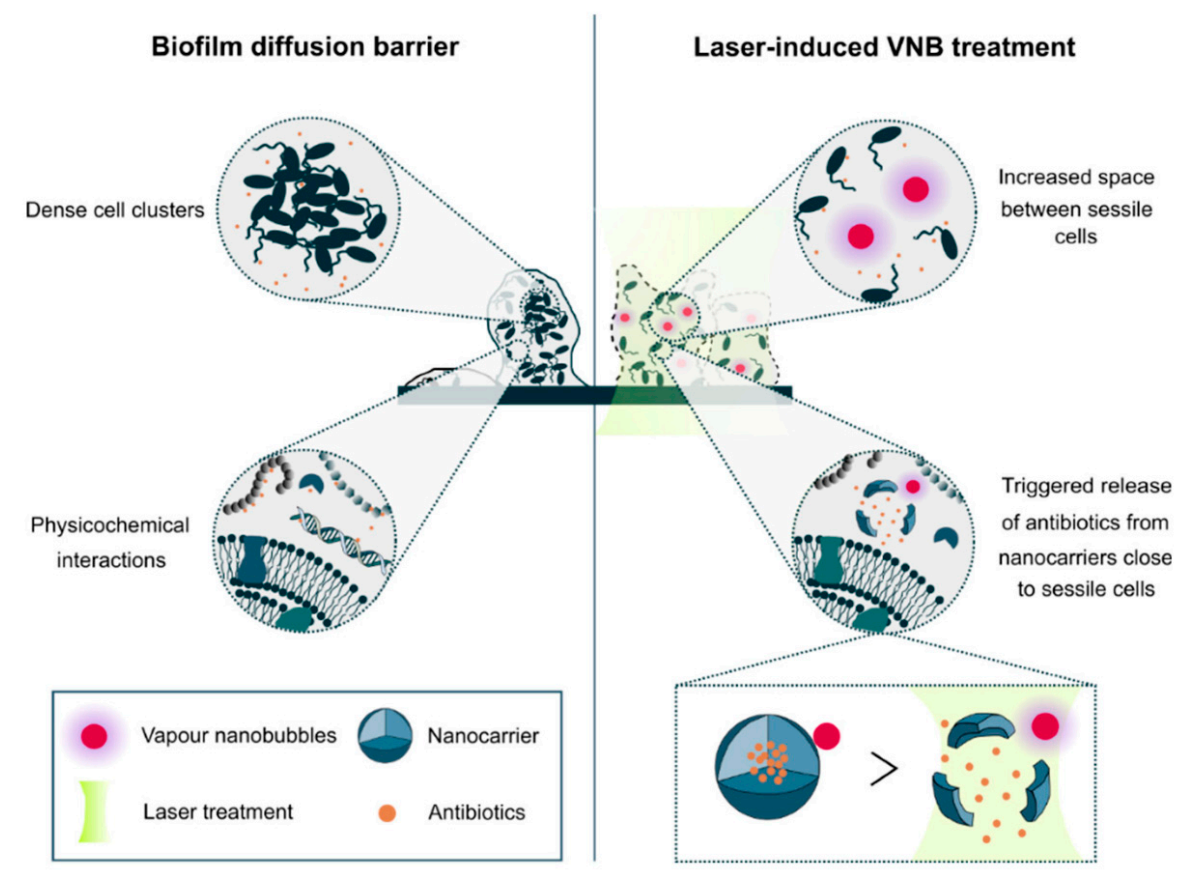

Figure 6. Laser-induced vapor nanobubbles (VNB) improved antibiotic delivery to biofilms. Impaired biofilm diffusion is caused by the fact that sessile cells cluster together into dense aggregates of hundreds of micrometers in size and because of the multi-component nature of the biofilm matrix which can trap molecules in their passage through biofilms. The mechanical impact of laser-induced VNB could increase the space between sessile cells, leading to a better flux and the effectivity of antimicrobial agents and their mechanical force can trigger antibiotic release from nanocarriers close to sessile bacteria (reproduced from [72] with permission from MDPI, 2019). 
Recently, graphitic carbon nitride $\left(\mathrm{g}-\mathrm{C}_{3} \mathrm{~N}_{4}\right)$ has been shown as an efficient photocatalyst and photodegrading agent, which generated reactive oxygen species (ROS). Bing et al. [73] developed a nanoplatform of g- $\mathrm{C}_{3} \mathrm{~N}_{4}$ nanosheets embedded with silver nanoparticles $\left(\mathrm{Ag} / \mathrm{g}-\mathrm{C}_{3} \mathrm{~N}_{4}\right)$. They showed that $\mathrm{Ag} / \mathrm{g}-\mathrm{C}_{3} \mathrm{~N}_{4}$ nanoplatforms could effectively kill approximately $100 \%$ of $E$. coli and S. aureus at a very low concentration $(50 \mu \mathrm{g} / \mathrm{mL})$ after $30 \mathrm{~min}$ of activation by visible light. The nanoplatform at $200 \mu \mathrm{g} / \mathrm{mL}$ also cleaved the biofilm polysaccharide linkages and caused approximately $70 \%$ disruption of $48 \mathrm{~h}$ old $S$. aureus biofilm and killed the residue bacteria in the remaining biofilm after $3 \mathrm{~h}$ of activation by light [73]. Shrestha et al. [52] reported another approach for bacterial biofilm treatment using chitosan nanoparticles functionalized with Rose Bengal (RB), a photosensitizer agent, to enhance photodynamic therapy. The nanohybrids at concentration $0.1 \mathrm{mg} / \mathrm{mL}$ effectively killed $100 \%$ Enterococcus faecalis (E. faecalis) after a $15 \mathrm{~min}$ continuous light illumination at an intensity of $2 \mathrm{~J} / \mathrm{cm}^{2}$ as compared to RB treatment only. Remarkably, the nanohybrids at concentration $0.3 \mathrm{mg} / \mathrm{mL}$ completely eradicated a 21-day old biofilm after $30 \mathrm{~min}$ of irradiation at an intensity of $20 \mathrm{~J} / \mathrm{cm}^{2}$ [52].

\subsubsection{Nanomaterials with Combination of Light and Environmental pH Stimulation}

The combination therapy concept has attracted significant interest to increase treatment efficacy. A study by $\mathrm{Hu}$ et al. provided an example of the ability to attack S. aureus (MRSA) biofilms and kill the bacteria by using near infrared light (NIR) and environmental $\mathrm{pH}$ [74]. The authors created a coating consisting of zwitterionic gold nanoparticles that stayed as a dispersion of positively charged particles in normal $\mathrm{pH}$, but turned into negatively charged particles at acidic $\mathrm{pH}$ (c.a. 5.5) in the bacterial biofilm. This conversion helped the particles to adhere electrostatically to the positively charged MRSA bacteria and to form aggregates. NIR irradiation then allowed the aggregates to convert and concentrate the photon energy into heat, causing local disruption of the biofilm. Meanwhile, the particles remained as well-dispersed particles in the normal $\mathrm{pH}$ and hence minimized photothermal damage to healthy tissue [74].

Deng et al. [75] also took advantage of the difference in $\mathrm{pH}$ between biofilm and healthy tissue to develop a sophisticated nanomaterial platform consisting of metal-organic framework (MOF) nanodots containing porphyrin and manganese dioxide embedded in human serum albumin for treating E. coli and S. aureus biofilms (Figure 7). Porphyrin absorbs light (maximum absorption occurs near a wavelength of $400 \mathrm{~nm}$ ) and induces formation of singlet oxygen and other oxygen species in the presence of molecular oxygen $[76,77]$. $\mathrm{MnO}_{2}$ was designed to increase the $\mathrm{O}_{2}$ production via $\mathrm{H}_{2} \mathrm{O}_{2}$ catalyzation. Once the platform entered an acidic $\mathrm{pH}$ microenvironment in the biofilm, NIR irradiation would facilitate their decomposition, thereby releasing porphyrin-containing MOF dots (pMOF) while simultaneously generating oxygen. It was designed such that under the activation of NIR, the pMOF further oxidized the $\mathrm{O}_{2}$ to create $\mathrm{ROS}$ such as singlet oxygen ${ }^{1} \mathrm{O}_{2}, \mathrm{OH}^{-}$radicals, and $\mathrm{O}^{2-}$ radicals to eradicate biofilm. This platform was shown to decrease $82 \%$ and $84 \%$ of E. coli and S. aureus growth, respectively, after $15 \mathrm{~min}$ irradiation in the absence of $\mathrm{H}_{2} \mathrm{O}_{2}$. In the present of $\mathrm{H}_{2} \mathrm{O}_{2}, 99 \%$ and $90 \%$ of E. coli and S. aureus growth was inhibited, respectively. The nanomaterials also disrupted $80 \%$ of $48 \mathrm{~h}$ old $S$. aureus biofilm using 15 min irradiation and $\mathrm{H}_{2} \mathrm{O}_{2}$. The material was further demonstrated to heal biofilm-infected abscesses in mice with no detectable damage to the surrounding healthy tissue [75]. 


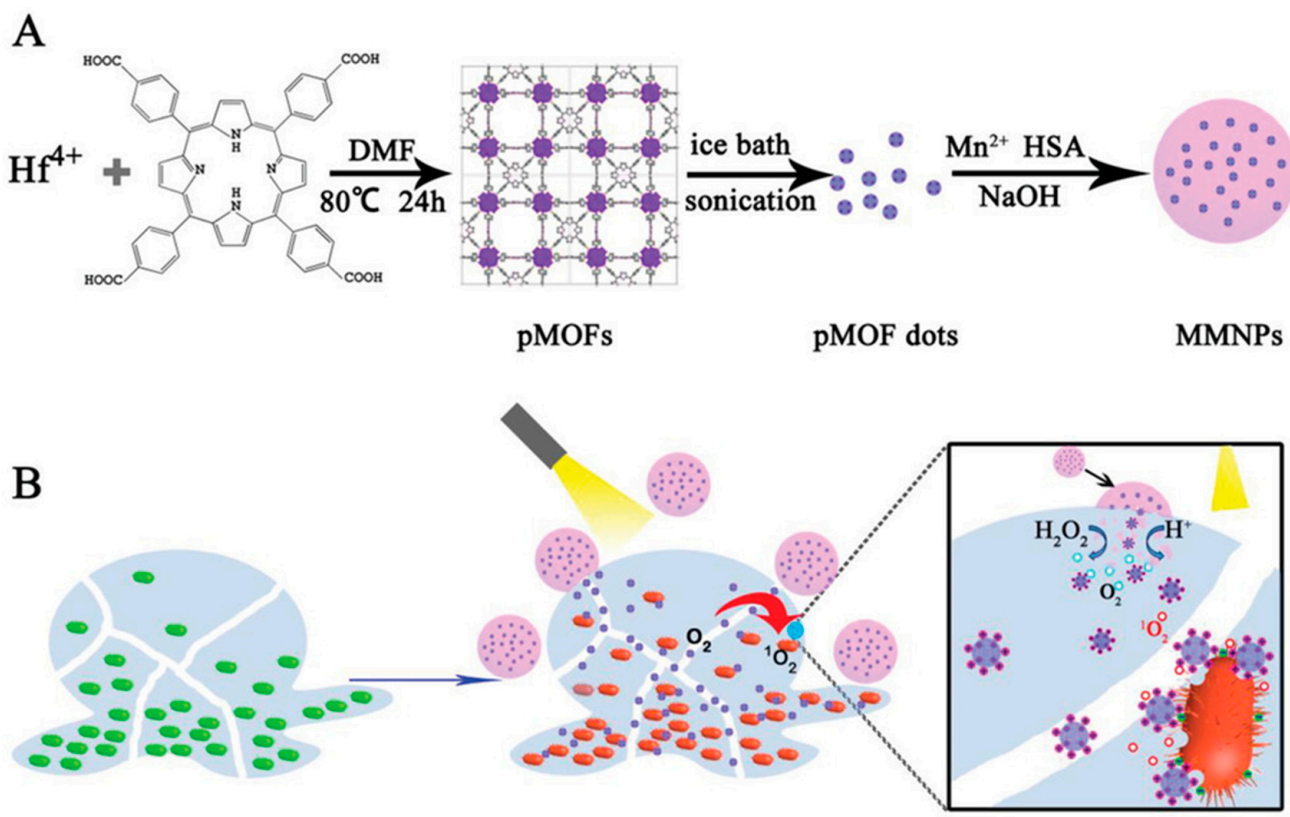

Figure 7. (A) Schematic illustration of nanomaterial fabrication for a multi-component nanoplatform (MMNPs) containing porphyrin-containing metal-organic framework (pMOF) dots. (B) Schematic of the mechanism of bacterial biofilm treatment by the nanoplatform (MMNPs) and external activation by NIR light. The MMNPs decomposed under an acidic environment, causing $\mathrm{MnO}_{2}$ degradation and pMOF dot release. The pMOF dots were then activated by NIR light to produce the reactive oxygen species. Additionally, in the presence of $\mathrm{H}_{2} \mathrm{O}_{2}, \mathrm{MnO}_{2}$ catalyzed $\mathrm{H}_{2} \mathrm{O}_{2}$ to form $\mathrm{O}_{2}$, enhancing the photodynamic therapy (reproduced from [75] with permission from John Wiley and Sons, 2019).

\section{Conclusions and Future Perspectives}

As the recurrence of bacterial infection in revision surgeries remains clinically significant, new methods for treating device-associated biofilms are urgently needed. A large number of nanomaterials have emerged as promising materials in preventing biofilm formation, yet not all have been demonstrated to be able to destroy biofilms. This is mainly due to the fact that bacterial biofilms present a highly resistant community of bacteria embedded within a matrix of their self-secreted extracellular polymer substance (EPS). Treating these biofilms involves destroying their EPS and killing these bacteria and, thus, is significantly more challenging than preventing biofilm formation. Some nanomaterials have been shown to possess intrinsic biofilm-eradicating properties, such as those reviewed in this paper, yet combinations of intrinsic bactericidal or EPS-lysing properties with stimulation (such as local $\mathrm{pH}$ or magnetic fields or light) are expected to significantly increase the treatment efficacy. We have summarized the studies cited in this review in Table 1 to provide a quick reference to the key materials for this development of new nanomaterials.

Key issues in using nanomaterials for biofilm treatment are their cytotoxicity and the fact that their fates in the body remains incompletely understood. For example, it is known that cationic nanoparticles are often also toxic to mammalian cells and easily recognized by the reticuloendothelial system [78-80]. Nanomaterials' toxicity strongly depends on their physicochemical properties such as shape, size, surface chemistry, structure, and agglomeration state [81]. Smaller sizes were often found with a higher level of toxicity, and agglomeration reduces the toxicity level [82]. Cytotoxicity also depends on the cell types in contact with the nanomaterials. For example, AuNP exhibit no significant toxic effects to dendritic cells, although they damage many other cell types [83]. The concerns of nanomaterial's cytotoxicity and complex tissue distribution following administration are common for all nanomaterials and have been extensively reviewed elsewhere and therefore will not be reviewed here again; rather, we would like to draw the attention to an issue that has been largely overlooked in current biofilm treatment approaches, as below. 
Table 1. A summary of nanomaterials for treating biofilms on medical devices.

\begin{tabular}{|c|c|c|c|c|c|c|c|}
\hline \multirow{2}{*}{$\begin{array}{l}\text { Activation } \\
\text { Mechanism }\end{array}$} & \multirow[b]{2}{*}{ Materials } & \multirow[b]{2}{*}{ Size and Shape } & \multirow[b]{2}{*}{ Preformed Bacterial Biofilm } & \multirow[b]{2}{*}{ Treatment Duration } & \multicolumn{2}{|c|}{ Antibiofilm Efficacy } & \multirow[b]{2}{*}{ Ref. } \\
\hline & & & & & $\begin{array}{c}\text { EPS } \\
\text { Disruption }\end{array}$ & $\begin{array}{c}\text { Bacterial } \\
\text { Killing }\end{array}$ & \\
\hline \multirow{7}{*}{ Intrinsic } & Biosynthesized AgNPs from P. zeylanica & $\begin{array}{c}\text { spheres } \\
15-295 \mathrm{~nm}\end{array}$ & $\begin{array}{c}24 \text { h-A. baumannii, E. coli, and } \\
\text { S. aureus } \\
24 \text { h-mixed species biofilm } \\
\text { (A. baumannii-S. aureus) }\end{array}$ & $24 \mathrm{~h}$ & $\begin{array}{l}88 \%, 67 \% \\
78 \%, 64 \%\end{array}$ & $96 \%$ to $99 \%$ & [38] \\
\hline & biosynthesized AgNPs from Acinetobacter calcoaceticus & $\begin{array}{l}\text { spheres } \\
4-40 \mathrm{~nm}\end{array}$ & $\begin{array}{l}24 \mathrm{~h} \text {-20 different pathogen } \\
\text { bacterial biofilm }\end{array}$ & $24 \mathrm{~h}$ & Up to $98 \%$ & NR & [39] \\
\hline & AuNPs + proteinase $\mathrm{K}$ & $\begin{array}{c}\text { spheres } \\
11-27 \mathrm{~nm}\end{array}$ & $\begin{array}{l}72 \mathrm{~h}-P \text { seudomonas fluorescens } \\
\text { biofilm }\end{array}$ & $24 \mathrm{~h}$ & $74 \%$ & $50 \%$ & [40] \\
\hline & Chitosan NPs $+\mathrm{O}_{3}$ oil & NR & $\begin{array}{l}24 \text { h-mixed-species biofilm } \\
\text { (S. mutans, E. faecalis, } \\
\text { and C. albicans) }\end{array}$ & 8 days & NR & $62.5 \%$ & [44] \\
\hline & Chitosan NPs & $\begin{array}{l}\text { spheres } \\
220 \pm 3 \mathrm{~nm}\end{array}$ & 7-day-E. faecalis biofilm & $72 \mathrm{~h}$ & $44 \%$ & $75-80 \%$ & [45] \\
\hline & PLGA + Octadecylamide NPs & $\begin{array}{l}\text { spheres } \\
217.7 \mathrm{~nm}\end{array}$ & 24 h-S. mutants biofilm & $72 \mathrm{~h}$ & NR & Up to $73 \%$ & [46] \\
\hline & $\begin{array}{c}\alpha \text {-TP + Phosphate } \\
\alpha \text {-TP + Trizma }\end{array}$ & $700 \mathrm{~nm}$ & $18 \mathrm{~h}$-multispecies oral biofilms & $2 \min$ & NR & $\sim 45 \%$ & [47] \\
\hline \multirow{8}{*}{ Nanocarriers } & chitosan + DNase I + oxacillin & $\begin{array}{l}\text { Spheres } \\
166.7 \mathrm{~nm}\end{array}$ & 24 h-S. aureus biofilm & $24 \mathrm{~h}$ & \multicolumn{2}{|c|}{ Up to $100 \%$} & [53] \\
\hline & Chitosan NPs + ciprofloxacin (Cip)+ Fucoidan & $\begin{array}{c}\text { spheres } \\
235 \pm 25 \mathrm{~nm}\end{array}$ & 48 h-S. Paratyphi A biofilm & $48 \mathrm{~h}$ & \multicolumn{2}{|c|}{$\begin{array}{l}62 \% \text { in vitro } \\
95 \% \text { in vivo }\end{array}$} & [54] \\
\hline & Gentamicin + phosphatidylcholine + AuNPs & $\begin{array}{l}\text { Spheres } \\
\sim 180 \mathrm{~nm}\end{array}$ & $\begin{array}{c}24 \mathrm{~h}-\text { P. aeruginosa biofilm } \\
24 \mathrm{~h}-\text { S. aureus biofilm } \\
24 \mathrm{~h}-\text { E. coli biofilm } \\
24 \mathrm{~h}-\text { L. monocytogenes biofilm }\end{array}$ & $24 \mathrm{~h}$ & \multicolumn{2}{|c|}{$\begin{array}{l}68.75 \% \\
66.67 \% \\
69.23 \% \\
65.38 \%\end{array}$} & [55] \\
\hline & PLGA -Poly(lysin) + DNase I + Cip & $\begin{array}{l}\text { spheres } \\
251.9 \mathrm{~nm}\end{array}$ & $\begin{array}{l}48 \text { h-P. aeruginosa biofilm } \\
24 \text { h-P. aeruginosa biofilm }\end{array}$ & $24 \mathrm{~h}$ & NR & $\begin{array}{l}43 \% \\
95 \%\end{array}$ & [56] \\
\hline & Silica + cinnamaldehyde NPs-peppermint oil capsule & $\begin{array}{c}\text { NPs: } \sim 150 \mathrm{~nm} \\
\text { Capsules: } 6.7 \pm 1.9 \mu \mathrm{m}\end{array}$ & $\begin{array}{l}24 \text { h-E. coli DH5, P. aeruginosa, } \\
\text { S. aureus, and E. cloacae }\end{array}$ & $3 \mathrm{~h}$ & $\mathrm{NR}$ & $90-100 \%$ & [57] \\
\hline & $\begin{array}{l}\text { copolymer Poly(oxanorborneneimide) bearing guanidine, } \\
\text { amine, and tetraethylene glycol monomethyl ether units + } \\
\text { poly(maleic anhydride--alt-octadecene + carvacrol oil }\end{array}$ & $\begin{array}{l}\text { Spheres: } \\
\sim 250 \mathrm{~nm}\end{array}$ & $\begin{array}{l}24 \text { h-E. coli DH5, P. aeruginosa, } \\
\text { S. aureus, and E. cloacae }\end{array}$ & $3 \mathrm{~h}$ & NR & $90-95 \%$ & [58] \\
\hline & Silica NPs + nitric oxide (NO) & $\begin{array}{c}\text { Spheres } \\
14-150 \mathrm{~nm}\end{array}$ & $\begin{array}{l}48 \text { h-S. aureus and P. aeruginosa } \\
\text { biofilm }\end{array}$ & $24 \mathrm{~h}$ & NR & $75 \%$ & [59] \\
\hline & $\begin{array}{c}\text { polyethylene glycol + glucose }+ \text { chitosan }+ \text { sodium nitrite }+ \\
\text { NO }\end{array}$ & $\begin{array}{l}\text { spheres } \\
10 \mathrm{~nm}\end{array}$ & $24 \mathrm{~h}-M R S A$ biofilm & $24 \mathrm{~h}$ & NR & $75 \%$ & [60] \\
\hline
\end{tabular}


Table 1. Cont.

\begin{tabular}{|c|c|c|c|c|c|c|c|}
\hline \multirow{2}{*}{$\begin{array}{c}\text { Activation } \\
\text { Mechanism }\end{array}$} & \multirow[b]{2}{*}{ Materials } & \multirow[b]{2}{*}{ Size and Shape } & \multirow[b]{2}{*}{ Preformed Bacterial Biofilm } & \multirow[b]{2}{*}{ Treatment Duration } & \multicolumn{2}{|c|}{ Antibiofilm Efficacy } & \multirow[b]{2}{*}{ Ref. } \\
\hline & & & & & $\begin{array}{c}\text { EPS } \\
\text { Disruption }\end{array}$ & $\begin{array}{c}\text { Bacterial } \\
\text { Killing }\end{array}$ & \\
\hline \multirow{3}{*}{$\begin{array}{c}\text { Local } \mathrm{pH} \text { or exogenous } \\
\qquad \mathrm{H}_{2} \mathrm{O}_{2}\end{array}$} & $\mathrm{Fe}_{3} \mathrm{O}_{4}+\mathrm{H}_{2} \mathrm{O}_{2}$ & $\begin{array}{l}\text { spheres } \\
500 \mathrm{~nm}\end{array}$ & Overnight $P$. aeruginosa biofilm & $2 \mathrm{~h}$ & \multicolumn{2}{|c|}{$82 \%$} & [67] \\
\hline & $\mathrm{IONs}+\mathrm{H}_{2} \mathrm{O}_{2}$ & $\begin{array}{c}\text { Spheres } \\
213 \pm 26 \mathrm{~nm}\end{array}$ & $19 \mathrm{~h}-\mathrm{S}$. mutants in vitro & $\begin{array}{l}5 \text { or } 10 \mathrm{~min}, \text { twice } \\
\text { daily, } 43 \mathrm{~h}\end{array}$ & $57-60 \%$ & $99.9 \%$ & [70] \\
\hline & DMAEMA + BMA + PAA + Farnesol & $\begin{array}{l}\text { Sphere } \\
\sim 60 \mathrm{~nm}\end{array}$ & $24 \mathrm{~h}-\mathrm{S}$. mutants biofilms & $44 \mathrm{~h}$ & $50 \%$ & $80 \%$ & [8] \\
\hline \multirow{5}{*}{ Light/heat } & Nanobubbles produced by AuNPs + tobramycin & $70 \mathrm{~nm}$ & $\begin{array}{l}24 \mathrm{~h}-\text { B. multivorans biofilm } \\
24 \mathrm{~h}-\text { P. aeruginosa biofilm } \\
24 \mathrm{~h} \text {-S. aureus biofilm }\end{array}$ & $\begin{array}{l}3 \text { min laser and } 24 \mathrm{~h} \\
\text { tobramycin }\end{array}$ & NR & $\begin{array}{l}98 \% \\
95 \% \\
96 \% \\
\end{array}$ & [71] \\
\hline & $\begin{array}{l}\text { phospholipid 1,2-dioleoyl-sn-glycero-3-phosphocholine+ } \\
\text { phospholipid 1,2-dipalmitoyl-sn-glycero-3 }\end{array}$ & \multirow{2}{*}{$\begin{array}{c}182 \pm 102 \mathrm{~nm} \\
39 \pm 14 \mathrm{~nm}\end{array}$} & \multirow{2}{*}{24 h-P. aeruginosa biofilm } & $\begin{array}{c}3 \text { min laser and } 24 \mathrm{~h} \\
\text { tobramycin }\end{array}$ & \multicolumn{2}{|c|}{$75 \%$} & \multirow[b]{2}{*}{ [72] } \\
\hline & $\begin{array}{l}\text {-phospho-( }\left(1^{\prime} \text {-rac-glycerol) AuNPs + tobramycin graphene }\right. \\
\text { quantum dot + AuNPs + tobramycin }\end{array}$ & & & $\begin{array}{l}15 \text { min laser exposure } \\
\text { and } 24 \mathrm{~h} \text { tobramycin }\end{array}$ & & & \\
\hline & $\mathrm{Ag} / \mathrm{g}-\mathrm{C}_{3} \mathrm{~N}_{4}$ & $\begin{array}{l}\text { g- } \mathrm{C}_{3} \mathrm{~N}_{4} \text { Nanosheet } \\
\text { AgNPs: } 6.5 \mathrm{~nm}\end{array}$ & 48 h-S. aureus biofilm & $3 \mathrm{~h}$ & $70 \%$ & $100 \%$ & [73] \\
\hline & Chitosan NPs + Rose Bengal & $\begin{array}{l}\text { spheres } \\
60 \pm 20 \mathrm{~nm}\end{array}$ & 21-day-biofilm & $\begin{array}{l}15 \text { min irradiation } \\
\text { from Lumacare lamp } \\
\text { at } 540 \pm 15 \mathrm{~nm}\end{array}$ & & & [52] \\
\hline \multirow{2}{*}{$\begin{array}{l}\text { Light and environmental } \\
\qquad \mathrm{pH}\end{array}$} & Citrate-caped AuNPs & $\begin{array}{l}\text { spheres } \\
14 \mathrm{~nm}\end{array}$ & $\begin{array}{l}24 \mathrm{~h} \text {-MRSA biofilm in vitro } \\
24 \mathrm{~h} \text {-subcutaneous abscess }\end{array}$ & $\begin{array}{c}60 \mathrm{~min} \\
10 \mathrm{~min} \text { NIR light } \\
\text { irradiation for } 7 \text { days }\end{array}$ & \multicolumn{2}{|c|}{$\begin{array}{l}92 \% \\
88 \%\end{array}$} & [74] \\
\hline & $\begin{array}{c}\text { pMOF nanodots }+ \text { porphyrin }+\mathrm{MnO}_{2}+\text { human serum } \\
\text { albumin }+\mathrm{H}_{2} \mathrm{O}_{2}\end{array}$ & $\begin{array}{l}\text { Spheres } \\
105 \mathrm{~nm}\end{array}$ & $\begin{array}{c}48 \text { h-S. aureus biofilm } \\
\text { 2-day-subcutaneous abscess }\end{array}$ & $\begin{array}{l}15 \text { min visible light } \\
\text { irradiation }\end{array}$ & \multicolumn{2}{|c|}{$\begin{array}{l}87.5 \% \\
99.9 \%\end{array}$} & [75] \\
\hline
\end{tabular}


Nanomaterial research in treating bacterial biofilms is expected to continue developing more sophisticated or more complex mechanisms of destroying the EPS and killing the embedded bacteria. Considering the significantly higher rates of infection to revision surgery of infected implants compared to primary implants, it is important that future development should not overlook the prevention of recurrence after biofilm treatment. In our opinion, as shown in Figure 8, this prevention can be achieved through in situ functionalizing the treated surface with agents that accelerate tissue growth on the surface, based on the concept of 'race for the surface' [84,85].

Step 1: ERADICATING BIOFILM

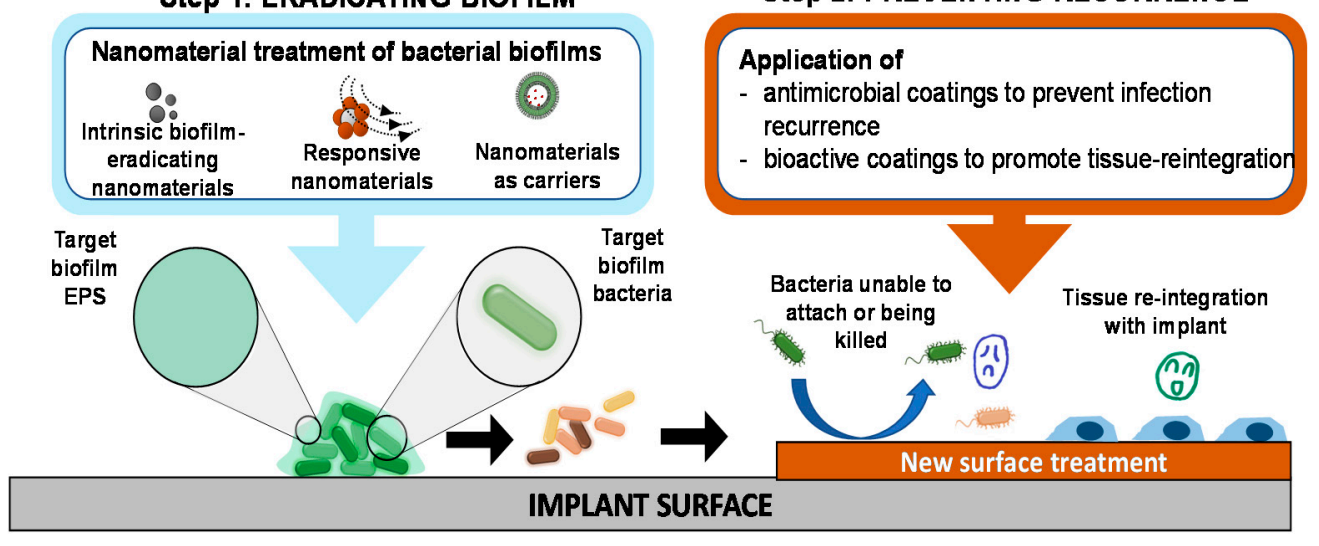

Figure 8. 'Eradicating-and-preventing' approach to medical device-associated biofilms. After the biofilm has been eradicated (step 1), the surface of the implant should be further treated (step 2, for example by coating with antimicrobial agents or bioactive coating or with bioactive agents to enable rapid tissue-implant reintegration) to prevent infection recurrence. This proposed approach is essentially a combination of treating biofilms and preventing biofilm formation.

Yet another challenge remaining is the fact that the use of chemical, thermal or photo-chemical reactions that allow coating process needs to be implemented directly on the implanted devices surrounded by host tissue. There are also some 'mild' coating methods [86-93] such as using catechol self-polymerization and surface functionalization chemistry, and photo-initiated crosslinking or surface-polymerization which should be further investigated to demonstrate biofilm treatment, recurrence prevention and tissue reintegration efficacy in vivo.

Author Contributions: Conceptualization, P.A.T.; data curation, H.M.T., H.T.; writing-original draft preparation, H.M.T., H.T.; writing—review and editing, H.M.T., H.T., M.A.B., K.E.F., N.T., T.H.N., P.A.T.; supervision, P.A.T.; funding acquisition, P.A.T. All authors have read and agreed to the published version of the manuscript.

Funding: P.A.T. is supported by the Advance Queensland Research Fellowship; K.E.F. is supported by the Clive and Vera Ramaciotti Foundation and acknowledges the Australian Research Council (ARC) for funding (IC160100026).

Acknowledgments: Elyssa Tran is acknowledged for her assistance in the graphical illustration in this manuscript.

Conflicts of Interest: The authors declare no conflict of interest.

\section{References}

1. Tran, N.; Tran, P.A. Nanomaterial-Based Treatments for Medical Device-Associated Infections. ChemPhysChem 2012, 13, 2481-2494. [CrossRef] [PubMed]

2. Hetrick, E.M.; Schoenfisch, M.H. Reducing implant-related infections: Active release strategies. Chem. Soc. Rev. 2006, 35, 780-789. [CrossRef] [PubMed]

3. Gnanadhas, D.P.; Elango, M.; Janardhanraj, S.; Srinandan, C.S.; Datey, A.; Strugnell, R.A.; Gopalan, J.; Chakravortty, D. Successful treatment of biofilm infections using shock waves combined with antibiotic therapy. Sci. Rep. 2015, 5, 17440. [CrossRef] [PubMed] 
4. Donlan, R.M. Biofilm Formation: A Clinically Relevant Microbiological Process. Clin. Infect. Dis. 2001, 33, 1387-1392. [CrossRef] [PubMed]

5. Ikuma, K.; Decho, A.W.; Lau, B.L.T. When nanoparticles meet biofilms-Interactions guiding the environmental fate and accumulation of nanoparticles. Front. Microbiol. 2015, 6, 591. [CrossRef]

6. Wang, L.-S.; Gupta, A.; Rotello, V.M. Nanomaterials for the Treatment of Bacterial Biofilms. ACS Infect. Dis. 2016, 2, 3-4. [CrossRef]

7. Davies, D.G.; Marques, C.N.H. A Fatty Acid Messenger Is Responsible for Inducing Dispersion in Microbial Biofilms. J. Bacteriol. 2009, 191, 1393. [CrossRef]

8. Horev, B.; Klein, M.I.; Hwang, G.; Li, Y.; Kim, D.; Koo, H.; Benoit, D.S.W. pH-Activated Nanoparticles for Controlled Topical Delivery of Farnesol To Disrupt Oral Biofilm Virulence. ACS Nano 2015, 9, 2390-2404. [CrossRef]

9. Estellés, A.; Woischnig, A.-K.; Liu, K.; Stephenson, R.; Lomongsod, E.; Nguyen, D.; Zhang, J.; Heidecker, M.; Yang, Y.; Simon, R.J.; et al. A high-affinity native human antibody disrupts biofilm from Staphylococcus aureus bacteria and potentiates antibiotic efficacy in a mouse implant infection model. Antimicrob. Agents Chemother. 2016, 60, 2292. [CrossRef]

10. Watters, C.M.; Burton, T.; Kirui, D.K.; Millenbaugh, N.J. Enzymatic degradation of in vitro Staphylococcus aureus biofilms supplemented with human plasma. Infect. Drug Resist. 2016, 9, 71-78. [CrossRef]

11. Hogan, S.; Zapotoczna, M.; Stevens, N.T.; Humphreys, H.; O'Gara, J.P.; O'Neill, E. Potential use of targeted enzymatic agents in the treatment of Staphylococcus aureus biofilm-related infections. J. Hosp. Infect. 2017, 96, 177-182. [CrossRef] [PubMed]

12. Mizan, M.F.R.; Jahid, I.K.; Ha, S.-D. Microbial biofilms in seafood: A food-hygiene challenge. Food Microbiol. 2015, 49, 41-55. [CrossRef] [PubMed]

13. Dellinger, E.P.; Gross, P.A.; Barrett, T.L.; Krause, P.J.; Martone, W.J.; McGowan, J.E., Jr.; Sweet, R.L.; Wenzel, R.P. Quality Standard for Antimicrobial Prophylaxis in Surgical Procedures. Clin. Infect. Dis. 1994, 18, $422-427$. [CrossRef] [PubMed]

14. Mangram, A.J.; Horan, T.C.; Pearson, M.L.; Silver, L.C.; Jarvis, W.R. Guideline for Prevention of Surgical Site Infection, 1999. Infect. Control Hosp. Epidemiol. 1999, 20, 247-280. [CrossRef] [PubMed]

15. Bratzler, D.W.; Dellinger, E.P.; Olsen, K.M.; Perl, T.M.; Auwaerter, P.G.; Bolon, M.K.; Fish, D.N.; Napolitano, L.M.; Sawyer, R.G.; Slain, D.; et al. Clinical Practice Guidelines for Antimicrobial Prophylaxis in Surgery. Surg. Infect. 2013, 14, 73-156. [CrossRef] [PubMed]

16. Jiranek, W.A.; Hanssen, A.D.; Greenwald, A.S. Antibiotic-Loaded Bone Cement for Infection Prophylaxis in Total Joint Replacement. JBJS 2006, 88, 2487-2500. [CrossRef]

17. Johnson, B.; Starks, I.; Bancroft, G.; Roberts, P.J. The effect of care bundle development on surgical site infection after hemiarthroplasty: An 8-year review. J. Trauma Acute Care Surg. 2012, 72, 1375-1379. [CrossRef]

18. Ramos, G.; Cornistein, W.; Cerino, G.T.; Nacif, G. Systemic antimicrobial prophylaxis in burn patients: Systematic review. J. Hosp. Infect. 2017, 97, 105-114. [CrossRef]

19. Gristina, A.G. Biomaterial-centered infection: Microbial adhesion versus tissue integration. Science 1987, 237, 1588-1595. [CrossRef]

20. Tenke, P.; Riedl, C.R.; Jones, G.L.; Williams, G.J.; Stickler, D.; Nagy, E. Bacterial biofilm formation on urologic devices and heparin coating as preventive strategy. Int. J. Antimicrob. Agents 2004, 23, 67-74. [CrossRef]

21. Roe, D.; Karandikar, B.; Bonn-Savage, N.; Gibbins, B.; Roullet, J.-B. Antimicrobial surface functionalization of plastic catheters by silver nanoparticles. J. Antimicrob. Chemother. 2008, 61, 869-876. [CrossRef] [PubMed]

22. Bazaka, K.; Jacob, M.V.; Crawford, R.J.; Ivanova, E.P. Efficient surface modification of biomaterial to prevent biofilm formation and the attachment of microorganisms. Appl. Microbiol. Biotechnol. 2012, 95, $299-311$. [CrossRef] [PubMed]

23. Romanò, C.; Tsuchiya, H.; Morelli, I.; Battaglia, A.; Drago, L. Antibacterial coating of implants: Are we missing something? Bone Jt. Res. 2019, 8, 199-206. [CrossRef] [PubMed]

24. Kunutsor, S.K.; Whitehouse, M.R.; Lenguerrand, E.; Blom, A.W.; Beswick, A.D.; Team, I. Re-Infection Outcomes Following One- And Two-Stage Surgical Revision of Infected Knee Prosthesis: A Systematic Review and Meta-Analysis. PLoS ONE 2016, 11, e0151537. [CrossRef] [PubMed]

25. Qasim, S.N.; Swann, A.; Ashford, R. The DAIR (debridement, antibiotics and implant retention) procedure for infected total knee replacement-A literature review. SICOT J. 2017, 3, 2. [CrossRef]

26. Bryers, J.D. Medical biofilms. Biotechnol. Bioeng. 2008, 100, 1-18. [CrossRef] 
27. Donlan, R.M. Biofilms and device-associated infections. Emerg. Infect. Dis. 2001, 7, 277. [CrossRef]

28. Hall-Stoodley, L.; Costerton, J.W.; Stoodley, P. Bacterial biofilms: From the natural environment to infectious diseases. Nat. Rev. Microbiol. 2004, 2, 95-108. [CrossRef]

29. Ferraris, S.; Spriano, S. Antibacterial titanium surfaces for medical implants. Mater. Sci. Eng. C 2016, 61, 965-978. [CrossRef]

30. Spriano, S.; Yamaguchi, S.; Baino, F.; Ferraris, S. A critical review of multifunctional titanium surfaces: New frontiers for improving osseointegration and host response, avoiding bacteria contamination. Acta Biomater. 2018, 79, 1-22. [CrossRef]

31. Verderosa, A.D.; Totsika, M.; Fairfull-Smith, K.E. Bacterial Biofilm Eradication Agents: A Current Review. Front. Chem. 2019, 7, 824. [CrossRef] [PubMed]

32. Seo, Y.; Hwang, J.; Lee, E.; Kim, Y.J.; Lee, K.; Park, C.; Choi, Y.; Jeon, H.; Choi, J. Engineering copper nanoparticles synthesized on the surface of carbon nanotubes for anti-microbial and anti-biofilm applications. Nanoscale 2018, 10, 15529-15544. [CrossRef] [PubMed]

33. Chendong, H.; Nicholas, R.; Stephen, F.; Julia, D.; Aaron, B.; Amber, L.D. Recent developments in the use of nanoparticles for treatment of biofilms. Nanotechnol. Rev. 2017, 6, 383-404. [CrossRef]

34. Mout, R.; Moyano, D.F.; Rana, S.; Rotello, V.M. Surface functionalization of nanoparticles for nanomedicine. Chem. Soc. Rev. 2012, 41, 2539-2544. [CrossRef] [PubMed]

35. Anderson, S.D.; Gwenin, V.V.; Gwenin, C.D. Magnetic Functionalized Nanoparticles for Biomedical, Drug Delivery and Imaging Applications. Nanoscale Res. Lett. 2019, 14, 188. [CrossRef] [PubMed]

36. Hiebner, D.W.; Barros, C.; Quinn, L.; Vitale, S.; Casey, E. Surface functionalization-dependent localization and affinity of $\mathrm{SiO}_{2}$ nanoparticles within the biofilm EPS matrix. Biofilm 2020, 2, 100029. [CrossRef]

37. Qayyum, S.; Khan, A.U. Nanoparticles vs. biofilms: A battle against another paradigm of antibiotic resistance. MedChemComm 2016, 7, 1479-1498. [CrossRef]

38. Salunke, G.R.; Ghosh, S.; Santosh Kumar, R.J.; Khade, S.; Vashisth, P.; Kale, T.; Chopade, S.; Pruthi, V.; Kundu, G.; Bellare, J.R.; et al. Rapid efficient synthesis and characterization of silver, gold, and bimetallic nanoparticles from the medicinal plant Plumbago zeylanica and their application in biofilm control. Int. J. Nanomed. 2014, 9, 2635-2653. [CrossRef]

39. Gaidhani, S.; Singh, R.; Singh, D.; Patel, U.; Shevade, K.; Yeshvekar, R.; Ananda Chopade, B. Biofilm disruption activity of silver nanoparticles synthesized by Acinetobacter calcoaceticus PUCM 1005. Mater. Lett. 2013, 108, 324-327. [CrossRef]

40. Habimana, O.; Zanoni, M.; Vitale, S.; O’Neill, T.; Scholz, D.; Xu, B.; Casey, E. One particle, two targets: A combined action of functionalised gold nanoparticles, against Pseudomonas fluorescens biofilms. J. Colloid Interface Sci. 2018, 526, 419-428. [CrossRef]

41. Huang, R.; Li, M.; Gregory, R.L. Bacterial interactions in dental biofilm. Virulence 2011, 2, 435-444. [CrossRef] [PubMed]

42. Renner, L.D.; Weibel, D.B. Physicochemical regulation of biofilm formation. MRS Bull. 2011, 36, 347-355. [CrossRef] [PubMed]

43. Flemming, H.-C.; Wingender, J. The biofilm matrix. Nat. Rev. Microbiol. 2010, 8, 623-633. [CrossRef] [PubMed]

44. Elshinawy, M.I.; Al-Madboly, L.A.; Ghoneim, W.M.; El-Deeb, N.M. Synergistic Effect of Newly Introduced Root Canal Medicaments; Ozonated Olive Oil and Chitosan Nanoparticles, Against Persistent Endodontic Pathogens. Front. Microbiol. 2018, 9, 1371. [CrossRef] [PubMed]

45. Shrestha, A.; Zhilong, S.; Gee, N.K.; Kishen, A. Nanoparticulates for Antibiofilm Treatment and Effect of Aging on Its Antibacterial Activity. J. Endod. 2010, 36, 1030-1035. [CrossRef] [PubMed]

46. Zhu, G.-Y.; Lu, B.-Y.; Zhang, T.-X.; Zhang, T.; Zhang, C.-L.; Li, Y.; Peng, Q. Antibiofilm effect of drug-free and cationic poly(D,L-lactide-co-glycolide) nanoparticles via nano-bacteria interactions. Nanomedicine 2018, 13, 1093-1106. [CrossRef]

47. Harper, R.A.; Carpenter, G.H.; Proctor, G.B.; Harvey, R.D.; Gambogi, R.J.; Geonnotti, A.R.; Hider, R.; Jones, S.A. Diminishing biofilm resistance to antimicrobial nanomaterials through electrolyte screening of electrostatic interactions. Colloids Surf. B Biointerfaces 2019, 173, 392-399. [CrossRef]

48. Forier, K.; Raemdonck, K.; De Smedt, S.C.; Demeester, J.; Coenye, T.; Braeckmans, K. Lipid and polymer nanoparticles for drug delivery to bacterial biofilms. J. Control. Release 2014, 190, 607-623. [CrossRef] 
49. Rukavina, Z.; Vanić, Ž. Current Trends in Development of Liposomes for Targeting Bacterial Biofilms. Pharmaceutics 2016, 8, 18. [CrossRef]

50. Wolfmeier, H.; Pletzer, D.; Mansour, S.C.; Hancock, R.E.W. New Perspectives in Biofilm Eradication. ACS Infect. Dis. 2018, 4, 93-106. [CrossRef]

51. Koo, H.; Allan, R.N.; Howlin, R.P.; Stoodley, P.; Hall-Stoodley, L. Targeting microbial biofilms: Current and prospective therapeutic strategies. Nat. Rev. Microbiol. 2017, 15, 740-755. [CrossRef] [PubMed]

52. Shrestha, A.; Hamblin, M.R.; Kishen, A. Photoactivated rose bengal functionalized chitosan nanoparticles produce antibacterial/biofilm activity and stabilize dentin-collagen. Nanomedicine 2014, 10, 491-501. [CrossRef] [PubMed]

53. Tan, Y.; Ma, S.; Leonhard, M.; Moser, D.; Haselmann, G.M.; Wang, J.; Eder, D.; Schneider-Stickler, B. Enhancing antibiofilm activity with functional chitosan nanoparticles targeting biofilm cells and biofilm matrix. Carbohydr. Polym. 2018, 200, 35-42. [CrossRef] [PubMed]

54. Elbi, S.; Nimal, T.R.; Rajan, V.K.; Baranwal, G.; Biswas, R.; Jayakumar, R.; Sathianarayanan, S. Fucoidan coated ciprofloxacin loaded chitosan nanoparticles for the treatment of intracellular and biofilm infections of Salmonella. Colloids Surf. B Biointerfaces 2017, 160, 40-47. [CrossRef]

55. Mu, H.; Tang, J.; Liu, Q.; Sun, C.; Wang, T.; Duan, J. Potent Antibacterial Nanoparticles against Biofilm and Intracellular Bacteria. Sci. Rep. 2016, 6, 18877. [CrossRef]

56. Baelo, A.; Levato, R.; Julián, E.; Crespo, A.; Astola, J.; Gavaldà, J.; Engel, E.; Mateos-Timoneda, M.A.; Torrents, E. Disassembling bacterial extracellular matrix with DNase-coated nanoparticles to enhance antibiotic delivery in biofilm infections. J. Control. Release 2015, 209, 150-158. [CrossRef]

57. Duncan, B.; Li, X.; Landis, R.F.; Kim, S.T.; Gupta, A.; Wang, L.-S.; Ramanathan, R.; Tang, R.; Boerth, J.A.; Rotello, V.M. Nanoparticle-Stabilized Capsules for the Treatment of Bacterial Biofilms. ACS Nano 2015, 9, 7775-7782. [CrossRef]

58. Landis, R.F.; Gupta, A.; Lee, Y.-W.; Wang, L.-S.; Golba, B.; Couillaud, B.; Ridolfo, R.; Das, R.; Rotello, V.M. Cross-Linked Polymer-Stabilized Nanocomposites for the Treatment of Bacterial Biofilms. ACS Nano 2017, 11, 946-952. [CrossRef]

59. Slomberg, D.L.; Lu, Y.; Broadnax, A.D.; Hunter, R.A.; Carpenter, A.W.; Schoenfisch, M.H. Role of Size and Shape on Biofilm Eradication for Nitric Oxide-Releasing Silica Nanoparticles. ACS Appl. Mater. Interfaces 2013, 5, 9322-9329. [CrossRef]

60. Mihu, M.R.; Cabral, V.; Pattabhi, R.; Tar, M.T.; Davies, K.P.; Friedman, A.J.; Martinez, L.R.; Nosanchuk, J.D. Sustained Nitric Oxide-Releasing Nanoparticles Interfere with Methicillin-Resistant Staphylococcus aureus Adhesion and Biofilm Formation in a Rat Central Venous Catheter Model. Antimicrob. Agents Chemother. 2017, 61. [CrossRef]

61. Cheeseman, S.; Christofferson, A.J.; Kariuki, R.; Cozzolino, D.; Daeneke, T.; Crawford, R.J.; Truong, V.K.; Chapman, J.; Elbourne, A. Antimicrobial Metal Nanomaterials: From Passive to Stimuli-Activated Applications. Adv. Sci. 2020, 7, 1902913. [CrossRef] [PubMed]

62. Suresh, M.K.; Biswas, R.; Biswas, L. An update on recent developments in the prevention and treatment of Staphylococcus aureus biofilms. Int. J. Med. Microbiol. 2019, 309, 1-12. [CrossRef] [PubMed]

63. Tran, N.; Webster, T.J. Magnetic nanoparticles: Biomedical applications and challenges. J. Mater. Chem. 2010, 20, 8760-8767. [CrossRef]

64. Taylor, E.N.; Kummer, K.M.; Durmus, N.G.; Leuba, K.; Tarquinio, K.M.; Webster, T.J. Superparamagnetic iron oxide nanoparticles (SPION) for the treatment of antibiotic-resistant biofilms. Small 2012, 8, 3016-3027. [CrossRef] [PubMed]

65. Leuba, K.D.; Durmus, N.G.; Taylor, E.N.; Webster, T.J. Short communication: Carboxylate functionalized superparamagnetic iron oxide nanoparticles (SPION) for the reduction of S. aureus growth post biofilm formation. Int. J. Nanomed. 2013, 8, 731-736. [CrossRef]

66. Zhang, C.; Du, C.; Liao, J.-Y.; Gu, Y.; Gong, Y.; Pei, J.; Gu, H.; Yin, D.; Gao, L.; Pan, Y. Synthesis of magnetite hybrid nanocomplexes to eliminate bacteria and enhance biofilm disruption. Biomater. Sci. 2019, 7, 2833-2840. [CrossRef]

67. Gao, L.; Giglio, K.M.; Nelson, J.L.; Sondermann, H.; Travis, A.J. Ferromagnetic nanoparticles with peroxidase-like activity enhance the cleavage of biological macromolecules for biofilm elimination. Nanoscale 2014, 6, 2588-2593. [CrossRef] 
68. Gao, L.; Zhuang, J.; Nie, L.; Zhang, J.; Zhang, Y.; Gu, N.; Wang, T.; Feng, J.; Yang, D.; Perrett, S.; et al. Intrinsic peroxidase-like activity of ferromagnetic nanoparticles. Nat. Nanotechnol. 2007, 2, 577-583. [CrossRef]

69. Wei, H.; Wang, E. Nanomaterials with enzyme-like characteristics (nanozymes): Next-generation artificial enzymes. Chem. Soc. Rev. 2013, 42, 6060-6093. [CrossRef]

70. Gao, L.; Liu, Y.; Kim, D.; Li, Y.; Hwang, G.; Naha, P.C.; Cormode, D.P.; Koo, H. Nanocatalysts promote Streptococcus mutans biofilm matrix degradation and enhance bacterial killing to suppress dental caries in vivo. Biomaterials 2016, 101, 272-284. [CrossRef]

71. Teirlinck, E.; Xiong, R.; Brans, T.; Forier, K.; Fraire, J.; Van Acker, H.; Matthijs, N.; De Rycke, R.; De Smedt, S.C.; Coenye, T.; et al. Laser-induced vapour nanobubbles improve drug diffusion and efficiency in bacterial biofilms. Nat. Commun. 2018, 9, 4518. [CrossRef]

72. Teirlinck, E.; Barras, A.; Liu, J.; Fraire, J.C.; Lajunen, T.; Xiong, R.; Forier, K.; Li, C.; Urtti, A.; Boukherroub, R.; et al. Exploring Light-Sensitive Nanocarriers for Simultaneous Triggered Antibiotic Release and Disruption of Biofilms Upon Generation of Laser-Induced Vapor Nanobubbles. Pharmaceutics 2019, 11, 201. [CrossRef] [PubMed]

73. Bing, W.; Chen, Z.; Sun, H.; Shi, P.; Gao, N.; Ren, J.; Qu, X. Visible-light-driven enhanced antibacterial and biofilm elimination activity of graphitic carbon nitride by embedded Ag nanoparticles. Nano Res. 2015, 8, 1648-1658. [CrossRef]

74. Hu, D.; Li, H.; Wang, B.; Ye, Z.; Lei, W.; Jia, F.; Jin, Q.; Ren, K.-F.; Ji, J. Surface-Adaptive Gold Nanoparticles with Effective Adherence and Enhanced Photothermal Ablation of Methicillin-Resistant Staphylococcus aureus Biofilm. ACS Nano 2017, 11, 9330-9339. [CrossRef] [PubMed]

75. Deng, Q.; Sun, P.; Zhang, L.; Liu, Z.; Wang, H.; Ren, J.; Qu, X. Porphyrin MOF Dots-Based, Function-Adaptive Nanoplatform for Enhanced Penetration and Photodynamic Eradication of Bacterial Biofilms. Adv. Funct. Mater. 2019, 29, 1903018. [CrossRef]

76. Abrahamse, H.; Hamblin, M.R. New photosensitizers for photodynamic therapy. Biochem. J. 2016, 473, 347-364. [CrossRef]

77. Sternberg, E.D.; Dolphin, D.; Brückner, C. Porphyrin-based photosensitizers for use in photodynamic therapy. Tetrahedron 1998, 54, 4151-4202. [CrossRef]

78. Lv, H.; Zhang, S.; Wang, B.; Cui, S.; Yan, J. Toxicity of cationic lipids and cationic polymers in gene delivery. J. Control. Release 2006, 114, 100-109. [CrossRef]

79. Bragonzi, A.; Boletta, A.; Biffi, A.; Muggia, A.; Sersale, G.; Cheng, S.H.; Bordignon, C.; Assael, B.M.; Conese, M. Comparison between cationic polymers and lipids in mediating systemic gene delivery to the lungs. Gene Ther. 1999, 6, 1995-2004. [CrossRef]

80. Samal, S.K.; Dash, M.; Van Vlierberghe, S.; Kaplan, D.L.; Chiellini, E.; van Blitterswijk, C.; Moroni, L.; Dubruel, P. Cationic polymers and their therapeutic potential. Chem. Soc. Rev. 2012, 41,7147-7194. [CrossRef]

81. Gatoo, M.A.; Naseem, S.; Arfat, M.Y.; Dar, A.M.; Qasim, K.; Zubair, S. Physicochemical properties of nanomaterials: Implication in associated toxic manifestations. Biomed. Res. Int. 2014, 2014, 498420. [CrossRef] [PubMed]

82. Vimbela, G.V.; Ngo, S.M.; Fraze, C.; Yang, L.; Stout, D.A. Antibacterial properties and toxicity from metallic nanomaterials. Int. J. Nanomed. 2017, 12, 3941-3965. [CrossRef] [PubMed]

83. Villiers, C.; Freitas, H.; Couderc, R.; Villiers, M.-B.; Marche, P. Analysis of the toxicity of gold nano particles on the immune system: Effect on dendritic cell functions. J. Nanopart. Res. 2010, 12, 55-60. [CrossRef]

84. Gristina, A.G.; Naylor P Fau-Myrvik, Q.; Myrvik, Q. Infections from biomaterials and implants: A race for the surface. Med. Prog. Technol. 1988, 14, 205. [PubMed]

85. Busscher, H.J.; van der Mei, H.C.; Subbiahdoss, G.; Jutte, P.C.; van den Dungen, J.J.A.M.; Zaat, S.A.J.; Schultz, M.J.; Grainger, D.W. Biomaterial-Associated Infection: Locating the Finish Line in the Race for the Surface. Sci. Transl. Med. 2012, 4, 153rv110. [CrossRef] [PubMed]

86. Tran, H.A.; Ly, K.L.; Fox, K.E.; Tran, P.A.; Nguyen, T.H. Immobilization of Antimicrobial Silver and Antioxidant Flavonoid as a Coating for Wound Dressing Materials. Int. J. Nanomed. 2019, 14, 9929-9939. [CrossRef]

87. Tran, H.A.; Tran, P.A. Immobilization-Enhanced Eradication of Bacterial Biofilms and in situ Antimicrobial Coating of Implant Material Surface-An in vitro Study. Int. J. Nanomed. 2019, 14, 9351-9360. [CrossRef] [PubMed] 
88. Li, M.; Liu, X.; Xu, Z.; Yeung, K.W.K.; Wu, S. Dopamine Modified Organic-Inorganic Hybrid Coating for Antimicrobial and Osteogenesis. ACS Appl. Mater. Interfaces 2016, 8, 33972-33981. [CrossRef]

89. Epstein, A.K.; Wong, T.-S.; Belisle, R.A.; Boggs, E.M.; Aizenberg, J. Liquid-infused structured surfaces with exceptional anti-biofouling performance. Proc. Natl. Acad. Sci. USA 2012, 109, 13182. [CrossRef]

90. Swartjes, J.J.T.M.; Das, T.; Sharifi, S.; Subbiahdoss, G.; Sharma, P.K.; Krom, B.P.; Busscher, H.J.; van der Mei, H.C. A Functional DNase I Coating to Prevent Adhesion of Bacteria and the Formation of Biofilm. Adv. Funct. Mater. 2013, 23, 2843-2849. [CrossRef]

91. Shi, L.; Santhanakrishnan, S.; Cheah, Y.S.; Li, M.; Chai, C.L.L.; Neoh, K.G. One-Pot UV-Triggered o-Nitrobenzyl Dopamine Polymerization and Coating for Surface Antibacterial Application. ACS Appl. Mater. Interfaces 2016, 8, 33131-33138. [CrossRef] [PubMed]

92. Zhou, C.; Wu, Y.; Thappeta, K.R.V.; Subramanian, J.T.L.; Pranantyo, D.; Kang, E.-T.; Duan, H.; Kline, K.; Chan-Park, M.B. In Vivo Anti-Biofilm and Anti-Bacterial Non-Leachable Coating Thermally Polymerized on Cylindrical Catheter. ACS Appl. Mater. Interfaces 2017, 9, 36269-36280. [CrossRef] [PubMed]

93. Adnan, N.N.M.; Sadrearhami, Z.; Bagheri, A.; Nguyen, T.-K.; Wong, E.H.H.; Ho, K.K.K.; Lim, M.; Kumar, N.; Boyer, C. Exploiting the Versatility of Polydopamine-Coated Nanoparticles to Deliver Nitric Oxide and Combat Bacterial Biofilm. Macromol. Rapid Commun. 2018, 39, 1800159. [CrossRef] [PubMed]

Publisher's Note: MDPI stays neutral with regard to jurisdictional claims in published maps and institutional affiliations.

(C) 2020 by the authors. Licensee MDPI, Basel, Switzerland. This article is an open access article distributed under the terms and conditions of the Creative Commons Attribution (CC BY) license (http://creativecommons.org/licenses/by/4.0/). 